\title{
Differential action of polyunsaturated fatty acids and eicosanoids on bleomycin-induced cytotoxicity to neuroblastoma cells and lymphocytes
}

\author{
Sailaja Polavarapu¹, Bilikere S. Dwarakanath², Undurti N. Das ${ }^{1,3}$
}

\author{
${ }^{1}$ BioScience Research Centre, Gayatri Vidya Parishad College of Engineering Campus, \\ Madhurawada, Andhra Pradesh, India \\ ${ }^{2}$ Institute of Nuclear Medicine and Allied Sciences, DRDO, New Delhi, India \\ ${ }^{3}$ UND Life Sciences, Battle Ground, USA
}

Submitted: 20 December 2016

Accepted: 24 February 2017

Arch Med Sci 2018; 14, 1: 207-229

DOI: https://doi.org/10.5114/aoms.2018.72244

Copyright $\odot 2017$ Termedia \& Banach

\begin{abstract}
Introduction: This study was conducted to examine whether bleomycin-induced growth inhibitory action on human neuroblastoma cells (IMR-32) is influenced by anti-inflammatory metabolites of polyunsaturated fatty acids (PUFAs): lipoxin A4 (LXA4), resolvin D1 and protectin D1 in vitro.

Material and methods: The in vitro study was conducted using monolayer cultures of exponentially growing IMR-32 cells. The effects of various PUFAs and eicosanoids and anti-inflammatory metabolites of PUFAs such as lipoxin A4 (LXA4), resolvin D1 and protectin D1 on the growth of IMR-32 cells and human lymphocytes in vitro were investigated. The potential of PUFAs, eicosanoids and LXA4, resolvin D1 and protectin D1 to modify the growth inhibitory effects of bleomycin was also studied in IMR-32 cells and human lymphocytes. Results: PUFAs inhibited the growth of $I M R-32$ cells (EPA $>D H A=A A>G L A=$ ALA $>$ DGLA $=L A)$ significantly $(p<0.001)$ while prostaglandins were found to be not effective. Bleomycin-induced growth inhibitory action on IMR-32 cells was augmented by PUFAs and its metabolites $(p<0.05)$. PUFAs and LXA4 did not inhibit the growth of human lymphocytes and bleomycin-induced growth inhibitory action was also not enhanced by these bioactive lipids.

Conclusions: Bioactive lipids have differential action on normal human lymphocytes and tumor cells in vitro. The apparent lack of effect of PUFAs in combination with bleomycin on the growth of human lymphocytes in comparison to their growth inhibitory action on IMR-32 cells suggests that PUFAs can be used in combination with bleomycin to target tumor cells with little concern over this combination's effect on the growth of human lymphocytes. Further studies are warranted to evaluate these differential effects under in vivo conditions.
\end{abstract}

Key words: polyunsaturated fatty acids, lipoxin A4, resolvin, protectin, prostaglandins, neuroblastoma, lymphocytes, bleomycin, cytotoxicity.

\section{Introduction}

It is well known that polyunsaturated fatty acids (PUFAs) have growth inhibitory action on several tumor cells of different types and when used in appropriate doses can, in fact, induce their apoptosis with significantly much less action on normal cells in vitro and in vivo [1-12]. It is generally, believed that increased generation of free radicals and formation and accumulation of toxic lipid peroxides $[2,3,7,8]$ are responsible for this

\author{
Corresponding author: \\ Dr. Undurti N. Das MD, FAMS, \\ FRSC \\ UND Life Sciences \\ 2221 NW $5^{\text {th }}$ St \\ Battle Ground \\ WA 98604, USA \\ P: 216-231-5548 \\ E-mail: Undurti@hotmail.com
}


growth inhibitory action of PUFAs on tumor cells. The ability of PUFAs to induce apoptosis have been attributed not only to their ability to induce significant oxidative stress [2, 3] but also to alter the miRNA/mRNA expression network and effects on endoplasmic reticulum stress capability [12, 13].

Previously, we showed that intratumoral injection of $\gamma$-linolenic acid (GLA) into the human glioma tumor bed can regress the tumors [5, 14-17]. In this context, it is noteworthy that PUFAs have been shown to reverse tumor cell drug resistance by enhancing uptake and reducing efflux of anti-cancer drugs that enhanced intracellular drug concentrations [7, 18-23].

The PUFAs are metabolized by cyclo-oxygenase (COX), lipoxygenase (LOX) and cytochrome P450 enzymes into several metabolites that may or may not suppress the growth of cancer cells. Hence, it is important to evaluate the action of various metabolites of PUFAs on the anti-cancer action of conventional chemotherapeutic drugs before embarking on using a combination of various PUFAs and anti-cancer drugs in cancer therapy. Such a study is important since some investigations suggested that the tumoricidal action of PUFAs is not dependent on the formation of COX and LOX products though, this has been disputed $[1,2,24-28]$. This is further complicated by the observation that the action of different products of PUFAs on the growth of cells depends on the dose and type of the compounds tested [25-36]. In addition, action of lipoxins, resolvins, protectins and maresins on the growth of tumor cells, which are also metabolites of PUFAs, is not well known though some studies have indicated that they may possess anti-proliferative properties [37-41].

In a recent study [42], we noted that almost all PUFAs have growth inhibitory action on human neuroblastoma (IMR-32) cells in vitro. To a large extent, the ability of fatty acids to inhibit growth of IMR-32 cells depended on the concentration of the fatty acid used, the duration of incubation and their ability to produce free radicals and lipid peroxides $[2,43,44]$. In this context, it is noteworthy that when normal and tumor cells are incubated with PUFAs they are likely to be converted to various metabolites that may have contradictory actions on their growth. Thus, the ultimate effect of PUFAs and their metabolites on the growth of treated cells may depend on the balance between pro- and anti-growth metabolites formed. In addition, one of the major side effects of anti-cancer drugs is to suppress the viability of lymphocytes that leads to immunosuppression and consequent susceptibility to various infections. Hence, it is important to know the action of various metabolites of PUFAs and a combination of PUFAs and their metabolites on the growth of tumor cells and human lymphocytes.
In the present study, we evaluated the effects of various PUFAs viz. prostaglandins, leukotrienes, lipoxins, resolvins and protectins on the cytotoxicity of bleomycin, a radiomimetic and anti-cancer drug on the growth of human neuroblastoma (IMR-32) cells and human lymphocytes in vitro.

\section{Material and methods}

\section{Reagents}

DMEM culture media, RPMI 1640 culture media, Histopaque-1077, fetal bovine serum (FBS), phytohemagglutinin, MTT (3-(4,5-dimethylthiazole-2 -yl)-2,5-diphenyltetrazolium bromide) and other cell culture constituents were purchased from Sigma Aldrich Chemicals Pvt. Ltd., Bangalore, India. Bleomycin was purchased from Cipla, Goa, India. All PUFAs (linolenic acid - LA; dihomo-GLA - DGLA; arachidonic acid - AA of the $n-6$ series; $\alpha$-linolenic acid - ALA; eicosapentaenoic acid - EPA; and docosahexaenoic acid - DHA of the $n-3$ series); and their metabolites (prostaglandins, lipoxin A4, protectins and resolvins) used in the present study were purchased from Cayman Chemical Company, California, USA.

\section{Cell culture conditions}

Human neuroblastoma cells (IMR-32), procured from National Center for Cell Science, Pune, India; was grown in DMEM media ( $\mathrm{pH}$ 7.4) supplemented with bicarbonate, $100 \mathrm{U} / \mathrm{ml}$ penicillin, $100 \mu \mathrm{g} / \mathrm{ml}$ streptomycin, $1.25 \mu \mathrm{g} / \mathrm{ml}$ amphotericin B, 10\% FBS at $37^{\circ} \mathrm{C}$ with $5 \% \mathrm{CO}_{2}$.

Cells were sub-cultured and harvested from the confluent cultures. Initially confluent cultures were washed with phosphate buffered saline (PBS, $\mathrm{pH}$ 7.4) and then treated with Trypsin (0.25\%) - EDTA $(0.02 \%)$ for $3 \mathrm{~min}$. Trypsin was inactivated by addition of equal volume of FBS and cell pellet was used for various studies as described below.

\section{Isolation and culture of human lymphocytes}

Heparinized whole blood samples were collected by venipuncture from the same healthy adult male (25 years) for all experiments. Lymphocytes were isolated from heparinized whole blood and used immediately. For isolation of lymphocytes, whole blood was layered on Histopaque-1077 and centrifuged at $400 \mathrm{rpm}$ for $30 \mathrm{~min}$ at room temperature. Lymphocytes were collected from interface and washed with RPMI-1640 media twice at $250 \mathrm{rpm}$ for $20 \mathrm{~min}$ each at room temperature. Isolated lymphocytes were cultured in RPMI-1640 media supplemented with $2 \mathrm{mM}$ L-glutamine, 100 $\mathrm{U} / \mathrm{ml}$ penicillin, $100 \mu \mathrm{g} / \mathrm{ml}$ streptomycin, $1.25 \mu \mathrm{g} /$ $\mathrm{ml}$ amphotericin $\mathrm{B}, 1.5 \%$ phytohaemagglutinin and $10 \% \mathrm{FBS}$ at $37^{\circ} \mathrm{C}$ with $5 \% \mathrm{CO}_{2}$. 


\section{Effects of bleomycin on the viability of IMR-32 cells in vitro}

Cells were plated at a density of $0.5 \times 10^{4}$ cells/ $100 \mu \mathrm{l}$ of culture media in 96-well plates. At the end of $48 \mathrm{~h}$ attachment period, cells were treated with different doses of bleomycin $(7.5-120 \mu \mathrm{g} / \mathrm{ml})$ for different periods of time (12-48 h) as per the experimental protocol. Viable cell numbers were measured after each treatment period using MTT assay as described previously [42]. The cell growth percentage was expressed as the percentage of cell growth compared with control in the same treatment group.

\section{Effect of PUFAs and their metabolites on the viability of IMR-32 cells}

Cells were plated at a density of $0.5 \times 10^{4}$ cells/ $100 \mu \mathrm{l}$ in 96-well plate using culture media and the cells were allowed to grow for $48 \mathrm{~h}$ which is the period needed for their attachment. After this initial attachment period, cells were treated with different doses of various PUFAs and their metabolites lipoxin A4, prostaglandins, resolvin D1 and protectin D1. At the end of the treatment, viable cells were measured by MTT assay as detailed above [42].

Effect of PUFAs and their metabolites on bleomycin-induced cytotoxicity to IMR-32 cells

Two types of studies (pre-treatment and simultaneous treatment schedules) were performed to study the effects of PUFAs, lipoxin A4, prostaglandins on bleomycin-induced cytotoxicity as described below. Bleomycin showed $\sim 50 \%$ cytotoxicity to IMR-32 cells at $60 \mu \mathrm{g} / \mathrm{ml}$ dose at the end of $24 \mathrm{~h}$ incubation and the same dose and incubation time were selected for further experiments.

In the pre-treatment schedule, cells $\left(0.5 \times 10^{4}\right.$ cells/ $100 \mu \mathrm{l})$ seeded in 96-well plate were first treated with different doses of PUFAs $(10,20$ and $30 \mu \mathrm{g} /$ $\mathrm{ml}) /$ lipoxin $\mathrm{A} 4$ (1, 5 and $10 \mathrm{ng} / \mathrm{ml}) /$ prostaglandins $(10,50$ and $100 \mathrm{ng} / \mathrm{ml})$ for $5 \mathrm{~h}$. After $5 \mathrm{~h}$, spent media was replaced with fresh media containing $60 \mu \mathrm{g} / \mathrm{ml}$ of bleomycin and incubated for an additional $24 \mathrm{~h}$. At the end of the treatment period, viable cells were measured by MTT assay [42].

In the simultaneous treatment schedule, IMR-32 cells were initially incubated with plain culture media for $5 \mathrm{~h}$. After $5 \mathrm{~h}$, cells were treated simultaneously with different doses of PUFAs (10, 20 and $30 \mu \mathrm{g} / \mathrm{ml}) /$ lipoxin A4 (1, 5 and $10 \mathrm{ng} / \mathrm{ml}) /$ prostaglandins $(10,50$ and $100 \mathrm{ng} / \mathrm{ml})$ and bleomycin $(60 \mu \mathrm{g} / \mathrm{ml})$ and incubated for an additional $24 \mathrm{~h}$. At the end of the treatment period, viable cell numbers were measured by MTT assay as described above.

\section{Effect of bleomycin on the viability of human lymphocytes in vitro}

Cells were plated at a density of $1 \times 10^{5}$ cells/ $100 \mu \mathrm{l}$ of culture media in 96-well plates. At the end of $24 \mathrm{~h}$, cells were treated with different doses of bleomycin $(30$ and $60 \mu \mathrm{g} / \mathrm{ml}$ ) for different periods of time $(16-44 \mathrm{~h})$. Viable cell numbers were measured after each treatment period using MTT assay. The cell viability was expressed as the percentage of cell growth compared with control in the same treatment group.

\section{Effect of PUFAs and their metabolites on the viability of human lymphocytes in vitro}

Cells were plated at a density of $1 \times 10^{5}$ cells/ $100 \mu \mathrm{l}$ in 96-well plate using RPMI culture media and cultured for $24 \mathrm{~h}$. Cells were treated with different doses of various PUFAs and their metabolite (lipoxin A4) for $32 \mathrm{~h}$ and $40 \mathrm{~h}$. At the end of the treatment, the viable cells were measured by MTT assay as detailed above.

\section{Effect of PUFAs and lipoxin A4 on bleomycin-induced cytotoxicity to human lymphocytes}

Two types of studies were carried out to evaluate the effects of various PUFAs/lipoxin A4 on bleomycin-induced cytotoxicity as described below. Bleomycin showed $58 \%$ and $46 \%$ cytotoxicity to human lymphocytes at $60 \mu \mathrm{g} / \mathrm{ml}$ dose during $32 \mathrm{~h}$ and $40 \mathrm{~h}$ incubation respectively and the same was selected for further experiments.

In the pre-treatment schedule, cells seeded in 96-well plate were first treated with different doses of PUFAs $(10,20$ and $30 \mu \mathrm{g} / \mathrm{ml}$ )/lipoxin A4 $(1,5$ and $10 \mathrm{ng} / \mathrm{ml})$ for $8 \mathrm{~h}$ and $12 \mathrm{~h}$. Subsequently $60 \mu \mathrm{g} / \mathrm{ml}$ bleomycin was added and further incubated for $40 \mathrm{~h}$. At the end of the treatment period, viable cell numbers were measured by MTT assay as described above.

In the simultaneous treatment schedule, cells seeded in 96-well plate were treated simultaneously with different doses of PUFAs (10, 20 and $30 \mu \mathrm{g} / \mathrm{ml}$ )/lipoxin A4 (1, 5 and $10 \mathrm{ng} / \mathrm{ml})$ and bleomycin $(60 \mu \mathrm{g} / \mathrm{ml})$ and incubated for another $32 \mathrm{~h}$ and $40 \mathrm{~h}$. At the end of the treatment period, viable cell numbers were measured by MTT assay as described above.

\section{Cytotoxicity of GLA/EPA + lipoxin A4/resolvin $\mathrm{D} 1 /$ protectin D1 on IMR-32 cells in vitro}

We next studied the effect of GLA (as a representative of $n-6$ fatty acids), EPA (as a representative of $n-3$ PUFAs), lipoxin A4, resolvin D1 and protectin D1 alone and in combination (GLA + lipoxin A4/resolvin D1/protectin D1 and EPA + lipoxin A4/ 
resolvin D1/protectin $\mathrm{D} 1$ ) on the viability of IMR32 cells in vitro. In this study, cells were plated at a density of $0.5 \times 10^{4}$ cells / $100 \mu \mathrm{l}$ in 96 -well plate using culture media and the cells were allowed to grow for $48 \mathrm{~h}$ which is the period needed for their attachment. After this initial attachment period, cells were treated with different doses of GLA/EPA and in combination with lipoxin A4/resolvin D1/ protectin D1 for 24, 48 and $72 \mathrm{~h}$. At the end of the treatment, the amount of tetrazolium salt converted to formazan (proportional to the number of viable cells) was measured by MTT assay [42].

\section{Statistical analysis}

The data obtained from these experiments were analyzed by paired t-test using MS-Ex- cel statistical analysis tool. Each treatment was performed in triplicate and repeated at least twice. All values obtained are expressed as mean \pm SEM.

\section{Results}

\section{Effect of bleomycin on the viability of IMR-32 cells in vitro}

IMR-32 cells exposed to bleomycin showed a concentration $(7.5-120 \mu \mathrm{g} / \mathrm{ml})$ and time (12-48 h) dependent cytotoxicity. Nearly $\sim 50 \%$ decrease in the viability was observed at $60 \mu \mathrm{g} / \mathrm{ml}$ of bleomycin at the end of $24 \mathrm{~h}$ of incubation (Figure $1 \mathrm{~A}$ ). Hence, all further studies were carried out using $60 \mu \mathrm{g} / \mathrm{ml}$ bleomycin.

\section{A}

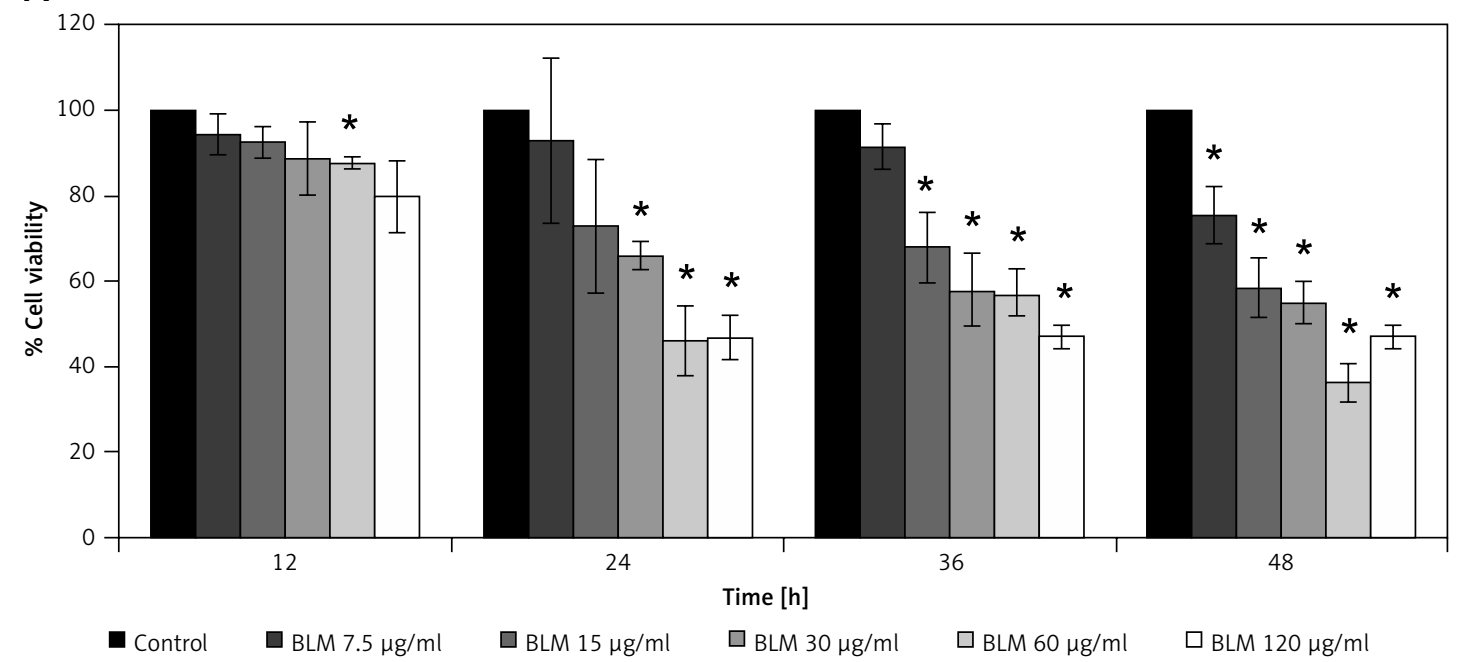

B

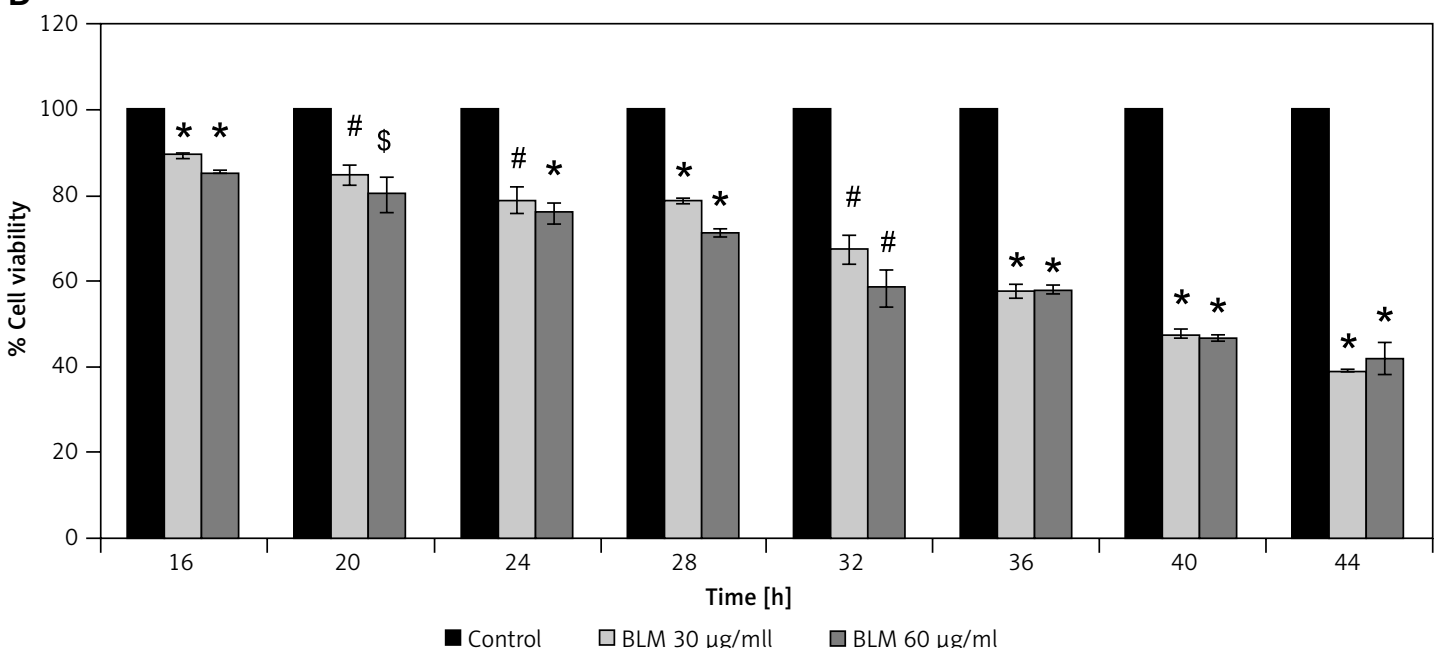

Figure 1. Dose and time optimization studies with bleomycin on IMR-32 cells and human lymphocytes. A - IMR-32 cells $\left(0.5 \times 10^{4}\right.$ cells $\left./ 100 \mu \mathrm{l}\right)$ were exposed to different doses of bleomycin $(7.5-120 \mu \mathrm{g} / \mathrm{ml})$ and incubated for $12-48 \mathrm{~h}$. At the end of the treatment period, cell viability was measured by MTT assay. B - Human lymphocytes were exposed to different doses of bleomycin $(30$ and $60 \mu \mathrm{g} / \mathrm{ml}$ ) and incubated for $16-44 \mathrm{~h}$. At the end of the treatment period, cell viability was measured by MTT assay

All values are expressed as mean \pm standard error $(n=6)$. ${ }^{*} p<0.001,{ }^{*} p<0.01$ and ${ }^{5} p<0.05$ compared to control. BLM - bleomycin. 
Effect of various PUFAs and their metabolites on the viability of IMR-32 cells in vitro

\section{Effect of PUFAs}

PUFAs: LA, AA, GLA, DGLA, ALA, EPA and DHA inhibited viability of IMR-32 cells to a significant degree when exposed to 10,20 and $30 \mu \mathrm{g} / \mathrm{ml}$ for $24 \mathrm{~h}$ when compared to control $(p<0.001$; Fig- ures $2 \mathrm{~A}, \mathrm{~B}$ ). Of all the PUFAs tested, EPA, DHA, ALA, $A A$ and GLA were found to be the most potent in decreasing the viability of IMR-32 cells compared to DGLA and LA (EPA > DHA = AA > GLA = ALA > $D G L A=L A)$ at the highest dose of $30 \mu \mathrm{g}$ tested at the end of $24 \mathrm{~h}$ of incubation. We next evaluated the effect of GLA (as a representative of $n-6$ fatty acids) and EPA (as a representative of $n-3$ fatty acids) on the viability of IMR-32 cells at 20,50 and
A

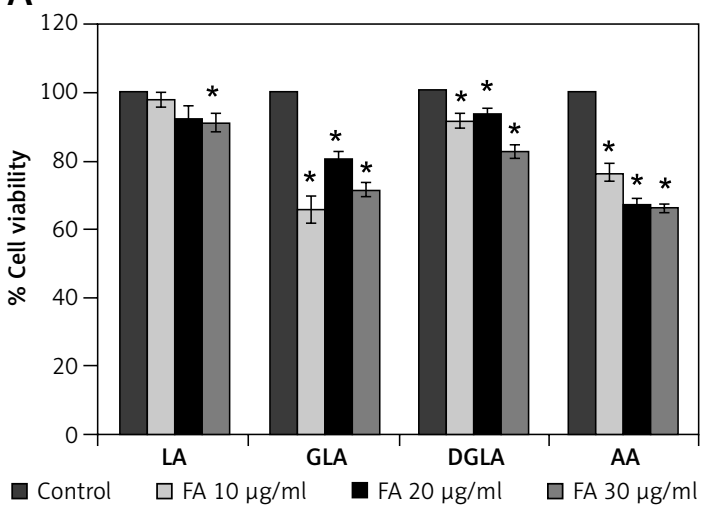

C

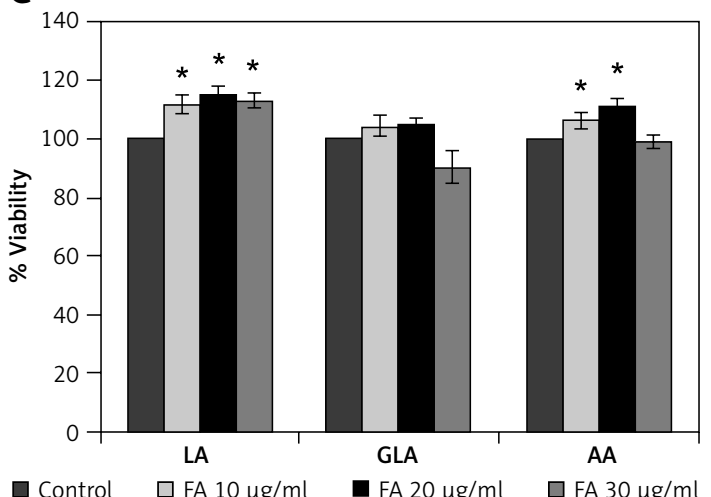

E

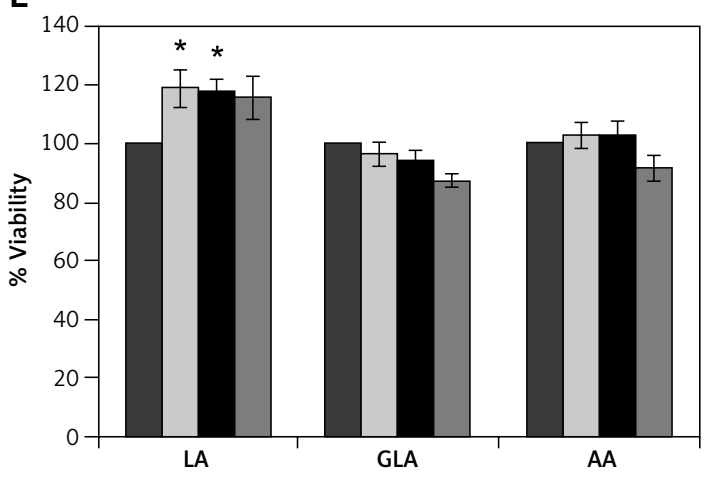

B

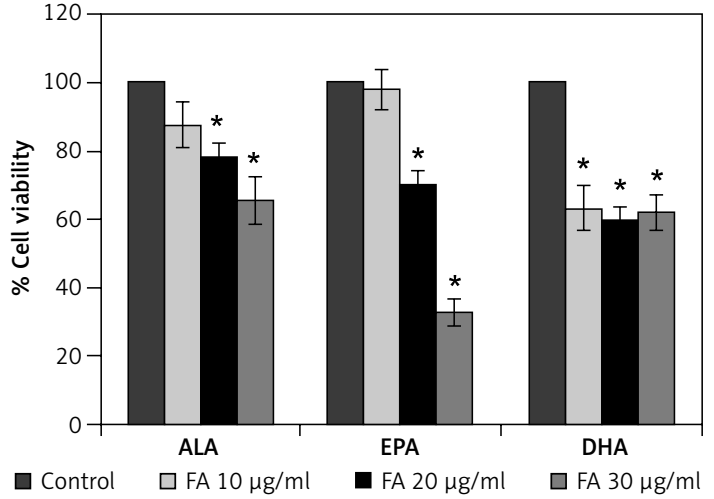

D

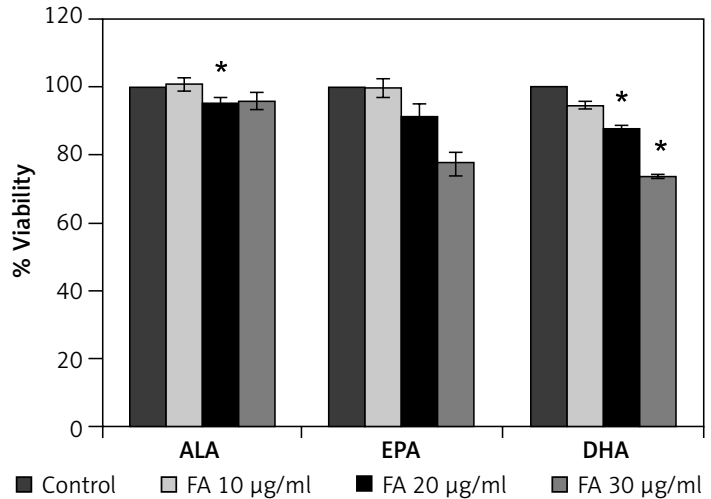

$\mathrm{F}$

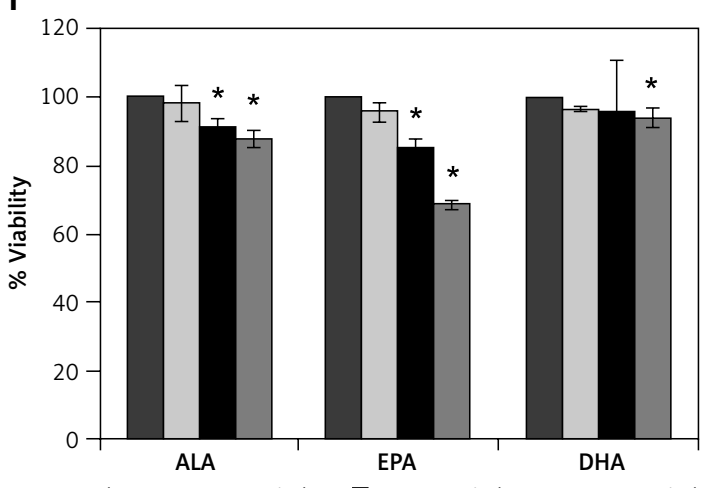

Control $\quad$ FA $10 \mu \mathrm{g} / \mathrm{ml} \quad$ FA $20 \mu \mathrm{g} / \mathrm{ml} \quad \square \mathrm{FA} 30 \mu \mathrm{g} / \mathrm{ml}$

Figure 2. Effect of PUFAs on viability of IMR-32 cells and human lymphocytes. IMR-32 cells $\left(0.5 \times 10^{4}\right.$ cells $\left./ 100 \mu l\right)$ were exposed to different doses $(10,20,30 \mu \mathrm{g} / \mathrm{ml})$ of $n-6(\mathbf{A})$ and $n-3$ (B) fatty acids and incubated for $24 \mathrm{~h}$. At the end of the treatment period, cell viability was assessed by MTT assay. Human lymphocytes were exposed to different doses $(10,20,30 \mu \mathrm{g} / \mathrm{ml})$ of $n-6$ (C, E) and $n-3$ (D, F) fatty acids and incubated for $32 \mathrm{~h}(\mathbf{C}, \mathbf{D})$ and $40 \mathrm{~h}$ (E, F). At the end of the treatment period, cell viability was measured by MTT assay

All values are expressed as mean \pm standard error $(n=6)$. ${ }^{*} P<0.05$ when compared to control. $L A-$ linoleic acid, $A A-$ arachidonic acid, GLA - $\gamma$-linolenic acid, DGLA - dihomo-gamma-linolenic acid, ALA - $\alpha$-linolenic acid, DHA - docosahexaenoic acid, EPA eicosapentaenoic acid. 
$100 \mu \mathrm{g} / \mathrm{ml}$. Results shown in Figures $3 \mathrm{~A}$ and $\mathrm{B}$ clearly indicate that both GLA and EPA have comparable degree of growth inhibitory action on IMR-32 cells.

\section{Effect of lipoxin A4}

Previously, we noted that both COX and LOX inhibitors (indomethacin and NDGA respectively) do not interfere with the cytotoxic action of PUFAs on IMR-32 cells [42]. Since COX and LOX products are predominantly pro-inflammatory prostaglandins (PGs), leukotrienes (LTs) and thromboxanes, we tested in the present study whether anti-inflammatory products of PUFAs such as lipoxin A4, resolvin D1 and protectin D1 can influence the survival of IMR-32 cells in vitro. The results of this study shown in Figures $3 \mathrm{C}-\mathrm{E}$ revealed that at the

A

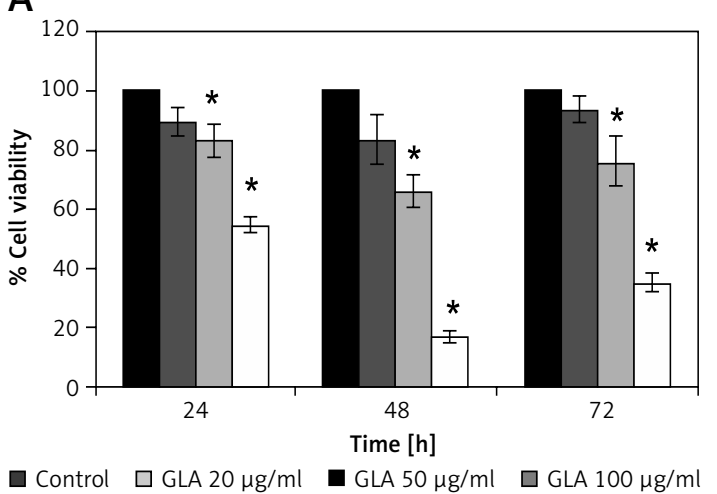

C

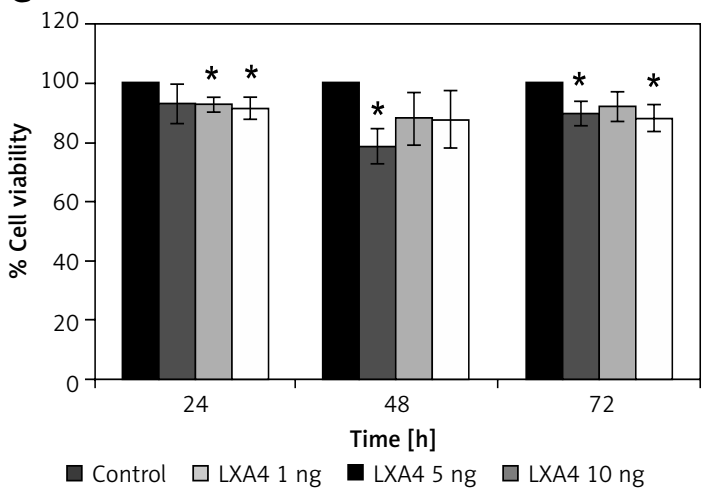

E

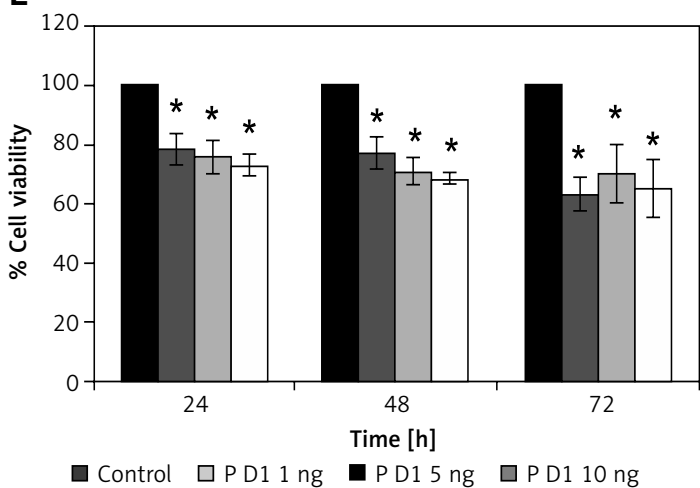

doses tested $(1,5$ and $10 \mathrm{ng} / \mathrm{ml})$ lipoxin $\mathrm{A} 4$, resolvin D1 and protectin D1 induced a significant reduction in the viability of IMR-32 cells at the end of $24 \mathrm{~h}$ of incubation $(p<0.001)$ in a dose-dependent manner compared to the control (resolvin D1 $>$ protectin D1 > LXA4), whereas at the end of 72 $h$ the efficiency of these bioactive lipids was as follows: protectin D1 > resolvin D1 > LXA4.

\section{Effect of prostaglandins}

Even though our previous studies revealed that both COX and LOX inhibitors did not interfere with the cytotoxic action of PUFAs on IMR-32 cells [42], to reconfirm those results, we examined the effect of different doses $(10,50$ and $100 \mathrm{ng} / \mathrm{ml})$ of various prostaglandins - PGE1, PGE2, PGF2 $\alpha$, PGI2 - for $24 \mathrm{~h}$ on the viability. These results showed that only

B

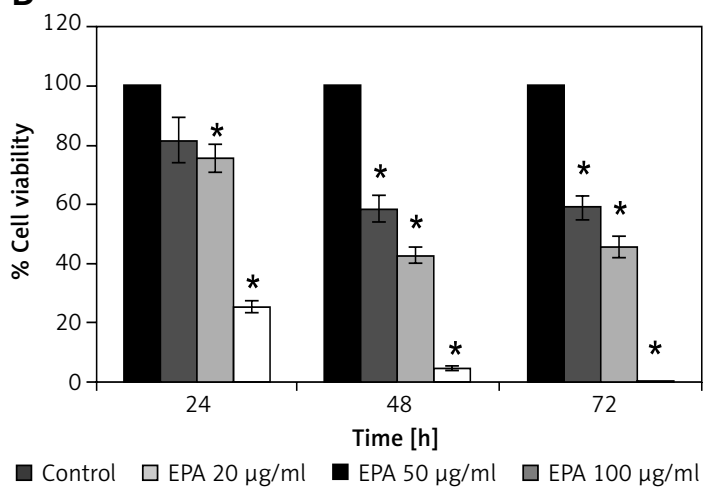

D

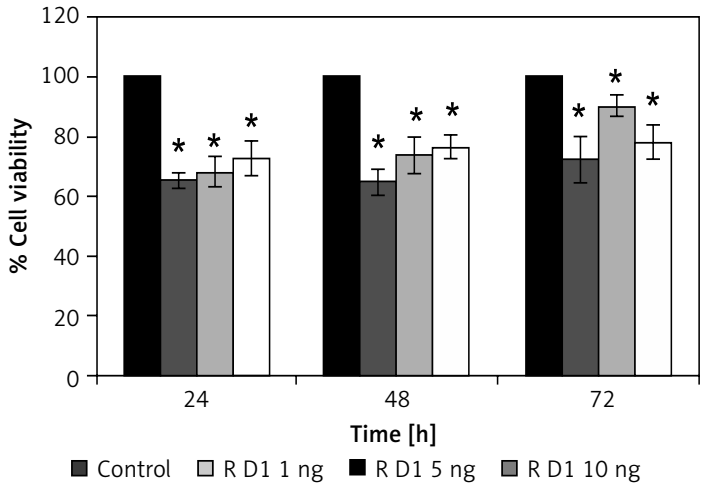

Figure 3. Effect of GLA/EPA/lipoxin A4/resolvin D1/ protectin D1 on the viability of IMR-32 cells. IMR-32 cells were exposed to different doses $(20,50,100$ $\mu \mathrm{g} / \mathrm{ml}$ ) of GLA (A)/EPA (B)/lipoxin A4 (C)/resolvin D1 (D)/protectin D1 (E) and incubated for 24, 48 and $72 \mathrm{~h}$. At the end of the treatment period, cell viability was measured by MTT assay

All values are expressed as mean \pm standard error $(n=6)$. ${ }^{*} P<0.05$ when compared to control. GLA - $\gamma$-linoleic acid, EPA - eicosapentaenoic acid, LXA4 - lipoxin A4, R D1 resolvin D1, PD1 - protectin D1. 
$\mathrm{PGE}_{1}$ and $\mathrm{PGE}_{2}$ induce a significant reduction $(p<$ $0.05)$ in the viability of IMR-32 cells (Figure 4 A).

\section{Effect of leukotrienes}

Similarly, we also tested the effect of LTD4 and LTE4 on the viability of IMR-32 cells at different doses $(10,50$ and $100 \mathrm{ng} / \mathrm{ml})$ for $24 \mathrm{~h}$. It was noted that LTD4 was more effective than LTE4 in inducing significant inhibition of viability of the cells (Figure 4 B, $p<0.01$ ) compared to the control.

\section{Effect of various PUFAs and their metabolites on bleomycin-induced cytotoxicity on IMR-32 cells in vitro}

In order to determine whether PUFAs and their various metabolites alter the growth inhibitory action of bleomycin on IMR-32 cells in vitro, we studied the effect of pre- and simultaneous exposure of these cells to PUFAs, prostaglandins, lipoxin A4 and bleomycin.

\section{Effect of PUFAs}

In the pre-treatment studies, IMR32 cells were first exposed to PUFAs for $5 \mathrm{~h}$, after which the medium was replaced with fresh medium containing bleomycin $(60 \mu \mathrm{g} / \mathrm{ml})$ and incubated for an additional $24 \mathrm{~h}$. At the end of the treatment period, viable cell numbers were measured by MTT assay. The results of this study given in Figure 5 revealed that GLA, DGLA, AA and EPA significantly $(p<0.05)$ enhanced bleomycin-induced growth inhibitory action on IMR-32 cells in both pre- and simultaneous treatment schedules. Of all the PUFAs tested, AA was the most effective in enhancing the growth inhibitory action of bleomycin on IMR-32 cells. Hence, further exper-

A

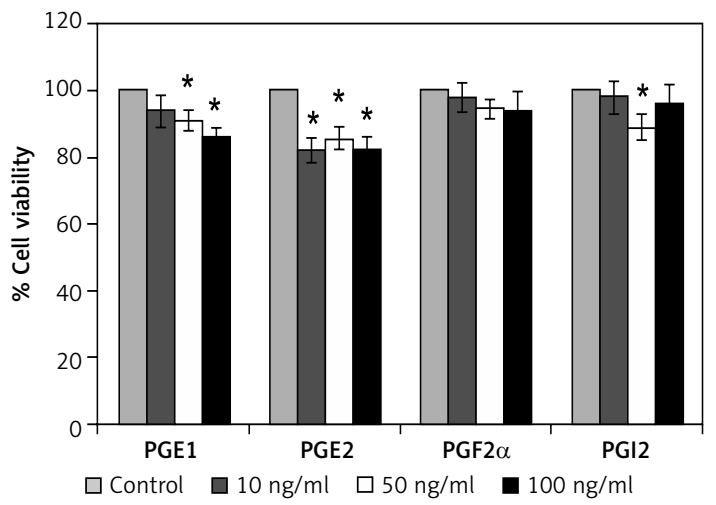

iments were focused on $A A$ and bleomycin on IMR-32 cells.

\section{Effect of prostaglandins on bleomycin- induced growth inhibitory action on IMR-32 cells}

PGE1, PGE2, PGF2 $\alpha$ and PGI2 tested both in the pre- and simultaneous treatment schedules did not influence the growth inhibitory action of bleomycin on IMR-32 cells in vitro, though in the simultaneous treatment schedule PGI2 enhanced the growth inhibitory action of bleomycin (Figure 6).

\section{Effect of COX and LOX inhibitors on IMR-32 cells}

Since prostaglandins and leukotrienes did not have any dramatic action on the growth of IMR-32 cells by themselves, whereas PUFAs not only inhibited their growth but also enhanced the growth inhibitory action of bleomycin, we next studied the effect of COX and LOX inhibitors - indomethacin and NDGA, respectively - on the growth of IMR-32 cells. IMR-32 cells were treated with indomethacin, a COX inhibitor $(20,40$ and $60 \mu \mathrm{g} / \mathrm{ml})$ and NDGA, a LOX inhibitor $(5,10$ and $20 \mu \mathrm{g} / \mathrm{ml})$. To our surprise, it was found that both indomethacin $(60 \mu \mathrm{g} / \mathrm{ml})$ and NDGA $(20 \mu \mathrm{g} / \mathrm{ml})$ significantly enhanced $(p<$ $0.001)$ IMR-32 cell viability compared to the control (Figures 7 A, B). These results suggested that both indomethacin and NDGA by themselves can enhance the growth of IMR-32 cells. These growth-enhancing actions of indomethacin and NDGA could be attributed to their inherent anti-oxidant actions $[45,46]$. This implies that in the presence of indomethacin and NDGA the growth inhibitory actions of prostaglandins and leukotrienes will be masked and possibly there is no role for PGs and LTs in the growth inhibitory actions of PUFAs on IMR-32 cells.

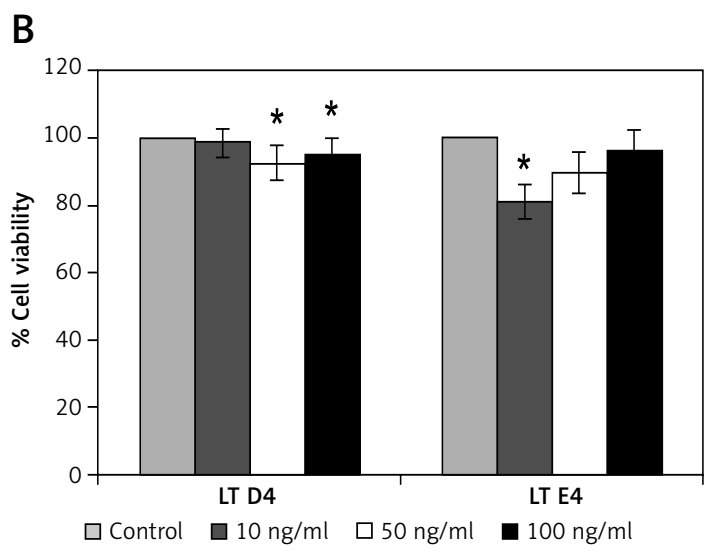

Figure 4. Effect of prostaglandin/leukotriene on viability of IMR-32 cells. IMR-32 cells were exposed to different doses (10, 50, $100 \mathrm{ng} / \mathrm{ml}$ ) of prostaglandin (PGE1, PGE2, PGF2 $\alpha$, PGI2) (A)/leukotrienes (D4, E4) (B) and incubated for $24 \mathrm{~h}$. At the end of the treatment period, cell viability was measured by MTT assay

All values are expressed as mean \pm standard error $(n=6)$. ${ }^{*} P<0.05$ when compared to control. PG - prostaglandin, $L T$ - leukotriene. 
A

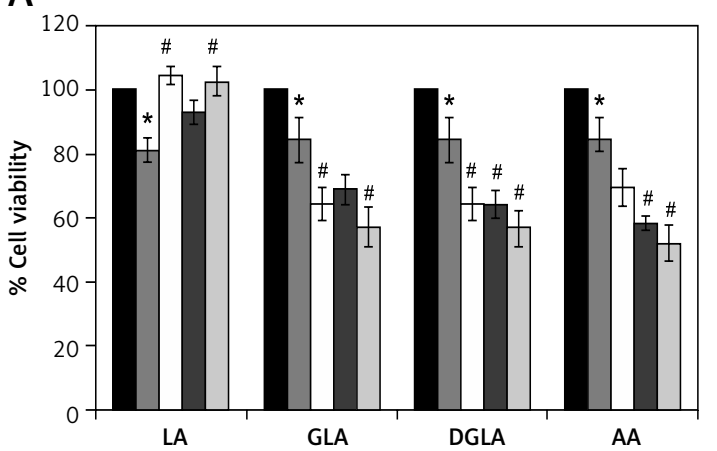

- Control $\square \mathrm{BLM} 60 \mu \mathrm{g} / \mathrm{ml} \quad \square \mathrm{FA} 10 \mu \mathrm{g} / \mathrm{ml}+\mathrm{BLM} 60 \mu \mathrm{g} / \mathrm{ml}$ 口 FA $20 \mu \mathrm{g} / \mathrm{ml}+\mathrm{BLM} 60 \mu \mathrm{g} / \mathrm{ml} \quad \square \mathrm{FA} 30 \mu \mathrm{g} / \mathrm{ml}+\mathrm{BLM} 60 \mu \mathrm{g} / \mathrm{ml}$

C

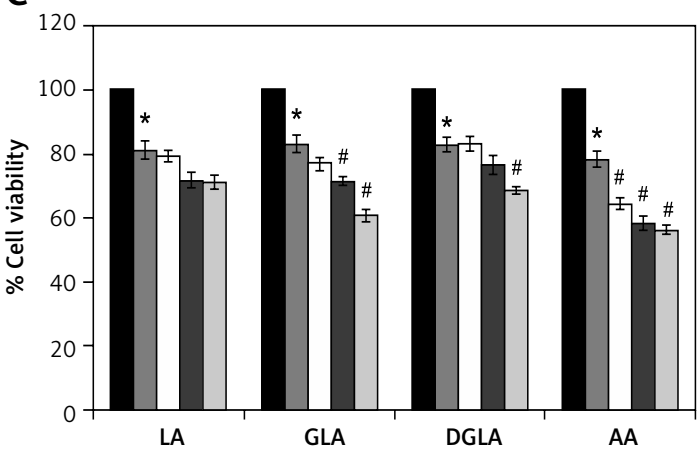

- Control $\square \mathrm{BLM} 60 \mu \mathrm{g} / \mathrm{ml} \quad \square \mathrm{FA} 10 \mu \mathrm{g} / \mathrm{ml}+\mathrm{BLM} 60 \mu \mathrm{g} / \mathrm{ml}$ 口FA $20 \mu \mathrm{g} / \mathrm{ml}+\mathrm{BLM} 60 \mu \mathrm{g} / \mathrm{ml} \quad$ FA $30 \mu \mathrm{g} / \mathrm{ml}+\mathrm{BLM} 60 \mu \mathrm{g} / \mathrm{ml}$
B

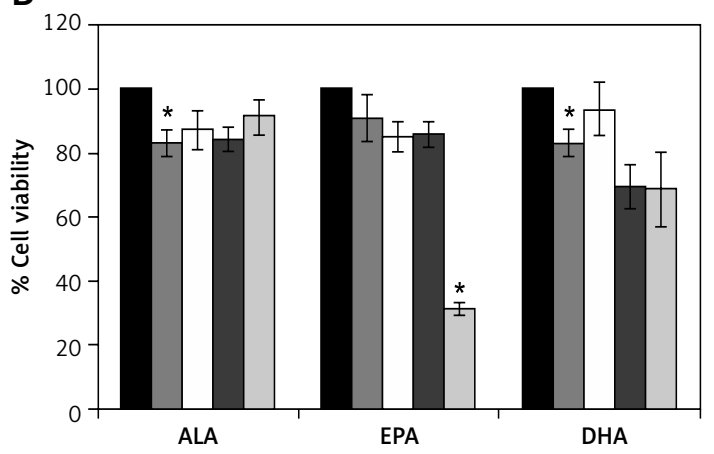

- Control $\square \mathrm{BLM} 60 \mu \mathrm{g} / \mathrm{ml} \quad \square \mathrm{FA} 10 \mu \mathrm{g} / \mathrm{ml}+\mathrm{BLM} 60 \mu \mathrm{g} / \mathrm{ml}$ $\square \mathrm{FA} 20 \mu \mathrm{g} / \mathrm{ml}+\mathrm{BLM} 60 \mu \mathrm{g} / \mathrm{ml} \quad \square \mathrm{FA} 30 \mu \mathrm{g} / \mathrm{ml}+\mathrm{BLM} 60 \mu \mathrm{g} / \mathrm{ml}$

D

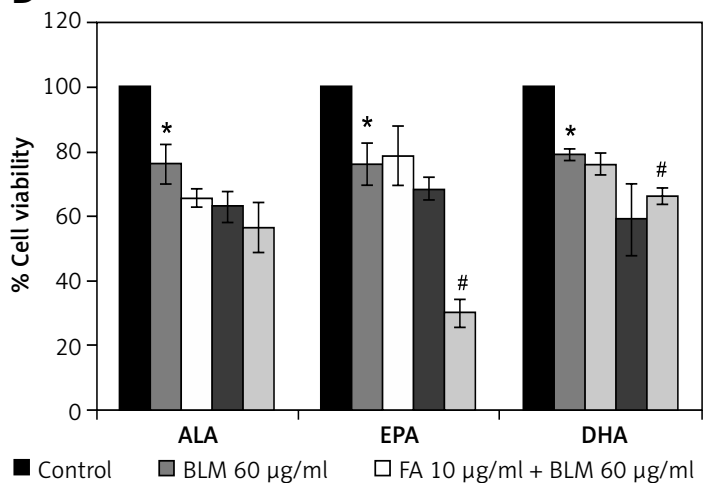

$\square$ FA $20 \mu \mathrm{g} / \mathrm{ml}+\mathrm{BLM} 60 \mu \mathrm{g} / \mathrm{ml} \quad \square$ FA $30 \mu \mathrm{g} / \mathrm{ml}+\mathrm{BLM} 60 \mu \mathrm{g} / \mathrm{ml}$

Figure 5. Effect of PUFAs on bleomycin-induced cytotoxicity in IMR-32 cells. Effect of pre-treatment with different doses $(10,20,30 \mu \mathrm{g} / \mathrm{ml})$ of $n-6$ (A) and $n-3$ (B) PUFAs on bleomycin $(60 \mu \mathrm{g} / \mathrm{ml})$-induced cytotoxicity to IMR-32 cells. Cells were pre-incubated with PUFAs for $5 \mathrm{~h}$ and then bleomycin for $24 \mathrm{~h}$ after which MTT assay was performed. Effect of simultaneous treatment with different doses $(10,20,30 \mu \mathrm{g} / \mathrm{ml})$ of $n-6$ (C) and $n-3$ (D) PUFAs on bleomycin $(60 \mathrm{\mu g} / \mathrm{ml})$-induced cytotoxicity to IMR-32 cells. Cells were pre-incubated with plain media for $5 \mathrm{~h}$ and then PUFAs and bleomycin were added and incubated for $24 \mathrm{~h}$ after which MTT assay was performed

All values are expressed as mean \pm standard error $(n=6)$. ${ }^{*} P<0.05$ when compared to control; ${ }^{*} p<0.05$ when compared to bleomycin. $L A$ - linoleic acid, AA - arachidonic acid, GLA - $\gamma$-linolenic acid, DGLA - dihomo- $\gamma$-linolenic acid, ALA - $\alpha$-linolenic acid, DHA - docosahexaenoic acid, EPA - eicosapentaenoic acid.

A

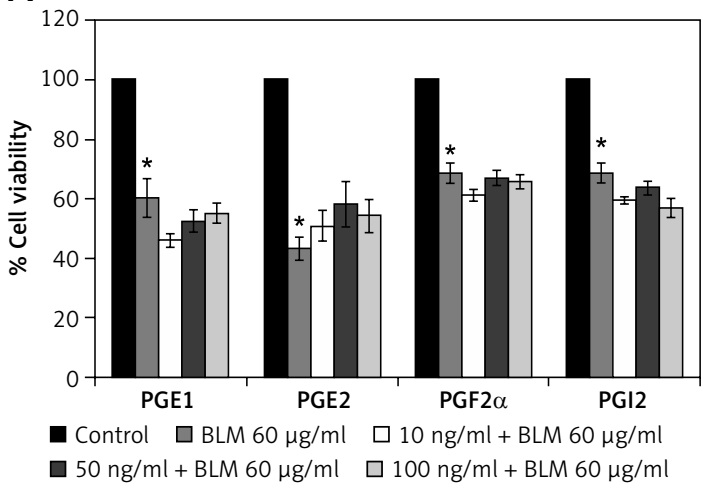

B

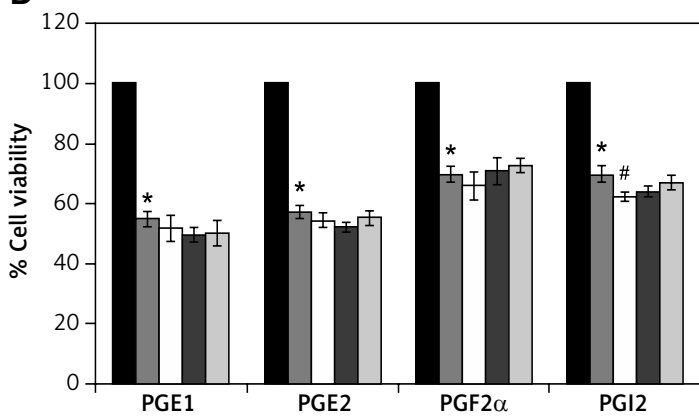

- Control $\square \mathrm{BLM} 60 \mu \mathrm{g} / \mathrm{ml} \quad \square 10 \mathrm{ng} / \mathrm{ml}+\mathrm{BLM} 60 \mu \mathrm{g} / \mathrm{ml}$ $\square 50 \mathrm{ng} / \mathrm{ml}+\mathrm{BLM} 60 \mu \mathrm{g} / \mathrm{ml} \quad \square 100 \mathrm{ng} / \mathrm{ml}+\mathrm{BLM} 60 \mu \mathrm{g} / \mathrm{ml}$

Figure 6. Effect of prostaglandins on bleomycin-induced cytotoxicity in IMR-32 cells. A - Effect of pre-treatment with different doses $(10,50,100 \mathrm{ng} / \mathrm{ml})$ of prostaglandins (PGE1, PGE2, PGF2 $\alpha$, PGI2) on bleomycin $(60 \mu \mathrm{g} / \mathrm{ml}$ )-induced cytotoxicity to IMR-32 cells. Cells were pre-incubated with prostaglandin for $5 \mathrm{~h}$ and then supplemented with bleomycin for $24 \mathrm{~h}$. B - Effect of simultaneous treatment with different doses (10, 50, $100 \mathrm{ng} / \mathrm{ml}$ ) of prostaglandin (PGE1, PGE2, PGF2 $\alpha$, PGI2) on bleomycin $(60 \mu \mathrm{g} / \mathrm{ml})$-induced cytotoxicity to IMR-32 cells. Cells were pre-incubated with plain media for $5 \mathrm{~h}$ and then prostaglandin and bleomycin were added simultaneously and incubated for an additional $24 \mathrm{~h}$ at the end of which MTT assay was performed.

All values are expressed as mean \pm standard error $(n=6)$. ${ }^{*} P<0.05$ when compared to control; ${ }^{*} p<0.05$ when compared to bleomycin. BLM - bleomycin, $P G$ - prostaglandin. 
Effect of cyclo-oxygenase (COX) and lipoxygenase (LOX) inhibitors on AA and bleomycin-induced growth inhibitory action on IMR-32 cells

To explore further the role of indomethacin and NDGA on the growth of IMR-32 cells, we next studied the effect of indomethacin and NDGA on the growth inhibitory actions of $A A$ and bleomycin. For this study, we used AA $30 \mu \mathrm{g} / \mathrm{ml}$ and bleomycin $60 \mu \mathrm{g} / \mathrm{ml}$ with or without indomethacin (20, 40 and $60 \mu \mathrm{g} / \mathrm{ml})$ or NDGA $(5,10$ and $20 \mu \mathrm{g}$ / $\mathrm{ml})$. AA, bleomycin and $A A+$ bleomycin induced significant inhibition in the growth of IMR-32 cells. At all the 3 concentrations tested, both indomethacin and NDGA produced a significant increase in the growth of IMR-32 cells (Figures 7 C and 7 D) even in the presence of $\mathrm{AA}$ and bleomycin.

\section{Effect of lipoxin A4 on bleomycin-induced cytotoxicity in IMR-32 cells}

To determine whether anti-inflammatory LXA4 can modulate the tumoricidal action of bleomy-

A

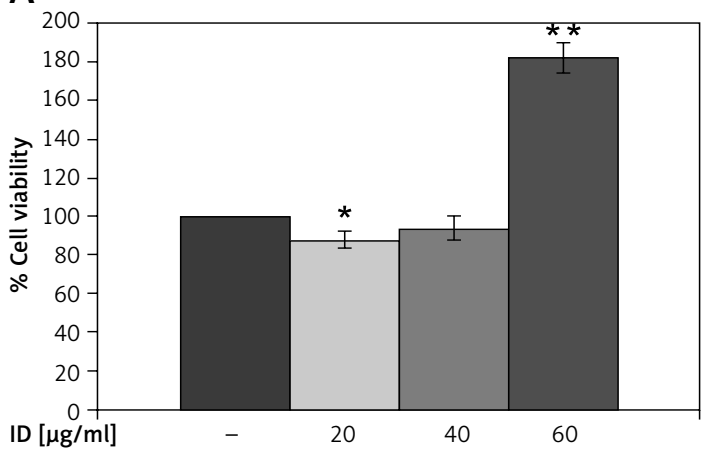

C

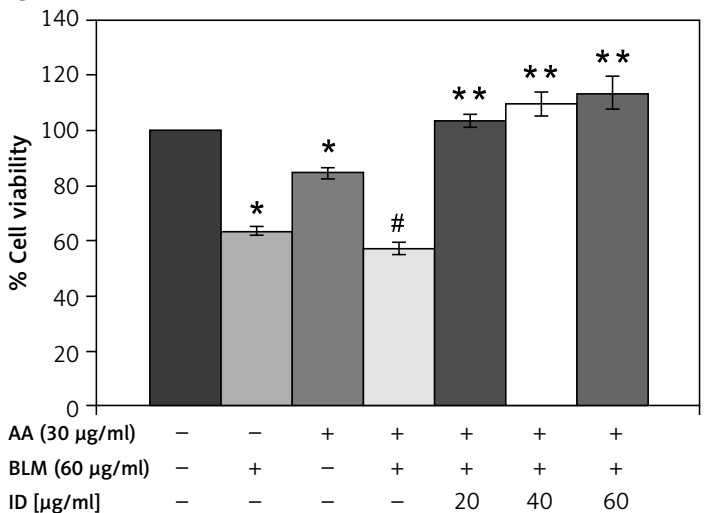

cin $(60 \mu \mathrm{g} / \mathrm{ml})$, we studied the effect of various doses $(1,5$, and $10 \mathrm{ng} / \mathrm{ml})$ of LXA4 at the end of 24,48 and $72 \mathrm{~h}$ of incubation. In this study, both pre- and simultaneous treatment schedules were employed. In the pre-incubation schedule, the cells were pre-incubated with 1,5 and $10 \mathrm{ng} / \mathrm{ml}$ of LXA4 for $5 \mathrm{~h}$, after which bleomycin was added and incubated for a further $24 \mathrm{~h}$, whereas in the simultaneous treatment schedule the cells were simultaneously exposed to both LXA4 and bleomycin for $24 \mathrm{~h}$. The results of this study showed that LXA4 neither enhanced nor inhibited the growth suppressive action of bleomycin, suggesting that LXA4 does not interfere with the anti-mitotic action of the anti-cancer drug (bleomycin) (Figure 8).

\section{Effect of a combination of GLA/EPA and LXA4/resolvin D1/protectin D1 on the viability of IMR-32 cells in vitro}

Since of all the PUFAs tested, GLA and AA of the $n-6$ series and EPA and DHA of the $n-3$ series and their anti-inflammatory metabolites LXA4, resolvin D1 and protectin D1 (protectin D1 > resolvin D1 >

B

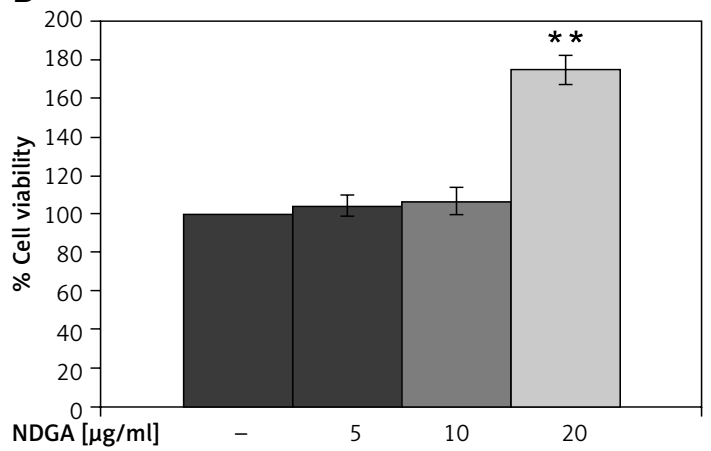

D

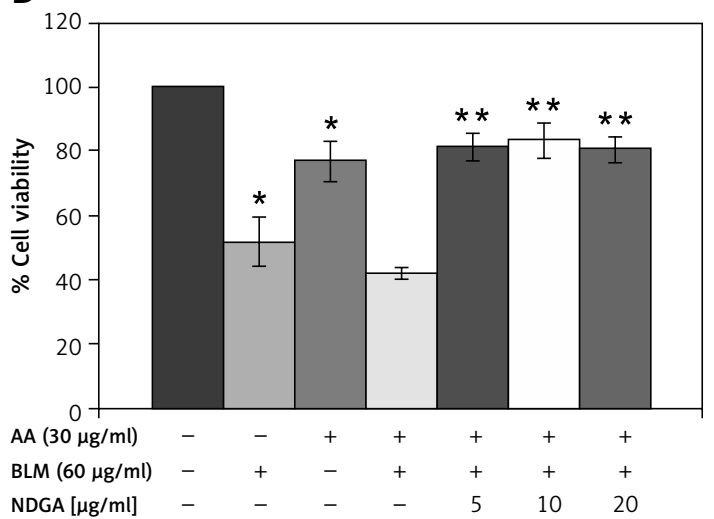

Figure 7. Effect of COX and LOX inhibitors on the viability of IMR-32 cells with and without bleomycin in the presence of arachidonic acid. A - Effect of indomethacin $(20,40,60 \mu \mathrm{g} / \mathrm{ml})$ on viability of IMR-32 cells during $24 \mathrm{~h}$ incubation. B - Effect of NDGA $(5,10,20 \mu \mathrm{g} / \mathrm{ml})$ on viability of IMR-32 cells during $24 \mathrm{~h}$ incubation. C - Effect of indomethacin $(20,40,60 \mu \mathrm{g} / \mathrm{ml})$ on arachidonic acid $(30 \mu \mathrm{g} / \mathrm{ml})+$ bleomycin action $(60 \mu \mathrm{g} / \mathrm{ml})$ on IMR32 cells during $24 \mathrm{~h}$ incubation. D - Effect of NDGA $(5,10,20 \mu \mathrm{g} / \mathrm{ml})$ on arachidonic acid $(30 \mu \mathrm{g} / \mathrm{ml})+$ bleomycin action $(60 \mathrm{\mu g} / \mathrm{ml})$ on IMR32 cells during $24 \mathrm{~h}$ incubation

All values are expressed as mean \pm standard error $(n=6)$. ${ }^{*} P<0.05$ when compared to control; ${ }^{* *} p<0.001$ when compared to $A A+B L M, " \# p<0.05$ when compared with bleomycin. $A A$ - arachidonic acid, BLM - bleomycin, ID - indomethacin, NDGA nordihydroguaiaretic acid. 
A

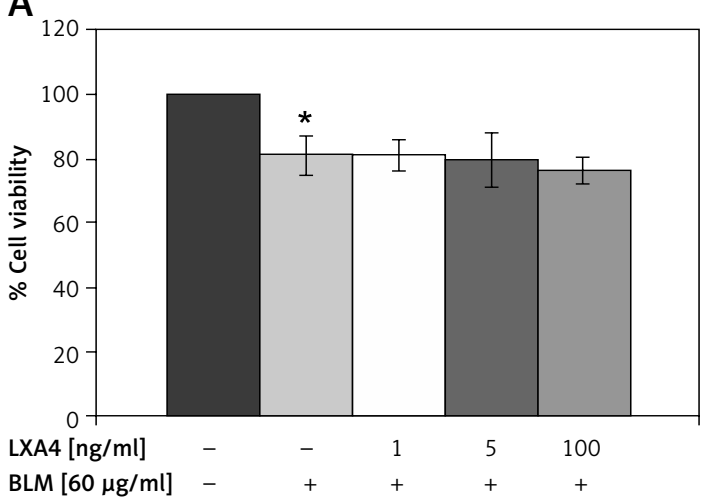

B

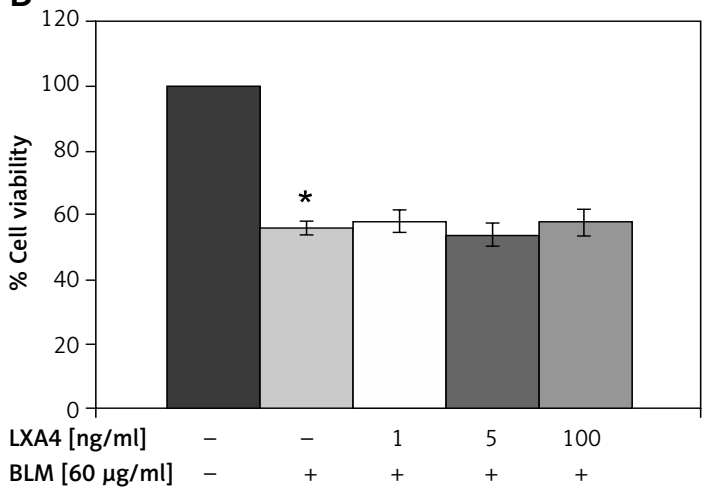

Figure 8. Effect of lipoxin A4 on bleomycin-induced cytotoxicity to IMR-32 cells. A - Effect of pre-treatment with different doses $(1,5,10 \mathrm{ng} / \mathrm{ml})$ of lipoxin A4 on bleomycin $(60 \mathrm{\mu g} / \mathrm{ml})$-induced cytotoxicity to IMR-32 cells. Cells were pre-incubated with lipoxin $\mathrm{A} 4$ for $5 \mathrm{~h}$ after which bleomycin was added and incubated for an additional $24 \mathrm{~h}$. B - Effect of simultaneous treatment with different doses $(1,5,10 \mathrm{ng} / \mathrm{ml})$ of lipoxin A4 on bleomycin $(60 \mathrm{\mu g} /$ $\mathrm{ml}$ )-induced cytotoxicity to IMR-32 cells. Cells were pre-incubated with plain media for $5 \mathrm{~h}$ and then lipoxin A4 and bleomycin were added simultaneously and incubated for $24 \mathrm{~h}$ after which MTT assay was performed

All values are expressed as mean \pm standard error $(n=6)$. ${ }^{*} P<0.05$ when compared to control. BLM - bleomycin, LXA4-lipoxin A4.

LXA4) showed significant growth inhibitory actions on IMR-32 cells in vitro (Figures 2, 3), we next wanted to know whether a combination of these PUFAs and their metabolites would potentiate each other's growth suppressive actions. For this study, we selected GLA as the representative of the $n-6$ series and EPA as the representative of the $n-3$ series. The results of this study shown in Figures 9-11 clearly revealed that when IMR-32 cells were supplemented with a combination of GLA (at 20, 50 and 100 $\mu \mathrm{g} / \mathrm{ml}$ ) and LXA4/resolvin D1/protectin D1 (at 1, 5 and $10 \mathrm{ng} / \mathrm{ml}$ ), there was a slight but statistically significant increase in the growth inhibitory action compared to the action of either GLA or LXA4/resolvin D1/protectin D1 alone, especially when this combination (GLA + LXA4/resolvin D1/protectin D1) was tested at the end of $48 \mathrm{~h}$ of incubation. Furthermore, this growth suppressive potentiating action of a combination of GLA and LXA4/resolvin D1/protectin D1 is more evident when the dose of GLA employed was 20 and $50 \mu \mathrm{g} / \mathrm{ml}$. On the other hand, when the dose of GLA employed was $100 \mu \mathrm{g} /$ $\mathrm{ml}$, its growth suppressive action was so overwhelmingly dominant that the inhibitory actions of LXA4/resolvin D1/protectin D1 became redundant.

Paradoxically, when similar studies were performed with a combination of EPA + LXA4/resolvin D1/protectin D1 the results were less impressive. For instance, a combination of $20 \mu \mathrm{g} / \mathrm{ml}$ of EPA + LXA4 (1, 5 and $10 \mathrm{ng} / \mathrm{ml}$ ) for 48 and $72 \mathrm{~h}$ produced no potentiation of the growth suppressive action of EPA and/or LXA4 on the viability of IMR-32 cells (Figure 12). On the other hand, a combination of EPA $(20 \mu \mathrm{g} / \mathrm{ml})+$ resolvin D1 $(1,5$ and $10 \mathrm{ng} / \mathrm{ml})$ in fact, enhanced viability of IMR-32 cells at the end of 48 and $72 \mathrm{~h}$ of supplementation (Figure 13), while at higher doses of EPA (50 and $100 \mu \mathrm{g} / \mathrm{ml})$ it induced significant suppression of the viability of
IMR-32 cells. Similar paradoxical results were also seen with protectin D1 (Figure 14). Thus, at higher concentrations (50 and $100 \mu \mathrm{g} / \mathrm{ml}$ ) EPA is a potent suppressor of viability of IMR-32 cells irrespective of the dose of LXA4/resolvin D1/protectin D1 employed. These results imply that when lower concentrations of EPA $(\sim 20 \mu \mathrm{g} / \mathrm{ml})$ and, possibly, DHA are used and if they are metabolized to form respective resolvins and protectins, it is likely that the growth suppressive actions of EPA and DHA might not be evident or even reversed.

Since the majority of the currently available anti-cancer drugs suppress the viability of human lymphocytes and thus produce immunosuppression, we next studied whether bleomycin and various PUFAs and their metabolites such as LXA4 (as a representative of anti-inflammatory products formed from PUFAs) influence viability of human lymphocytes in vitro.

\section{Effect of bleomycin on viability of human lymphocytes in vitro}

When human lymphocytes were exposed to different concentrations of bleomycin (30 and $60 \mu \mathrm{g} / \mathrm{ml})$ for different periods of time $(16-44 \mathrm{~h})$, $60 \mu \mathrm{g} / \mathrm{ml}$ decreased their viability by $58 \%$ and $46 \%$ at the end of $32 \mathrm{~h}$ and $40 \mathrm{~h}$ of incubation respectively (Figure $1 \mathrm{~B}$ ). Hence, all further studies were performed using $60 \mu \mathrm{g} / \mathrm{ml}$.

\section{Effect of PUFAs and their metabolites on viability of human lymphocytes in vitro}

\section{Effect of PUFAs}

Out of all PUFAs (LA, AA, GLA, ALA, EPA and DHA) tested, LA showed significant $(p<0.001)$ enhancement of viability of human lymphocytes when 
A

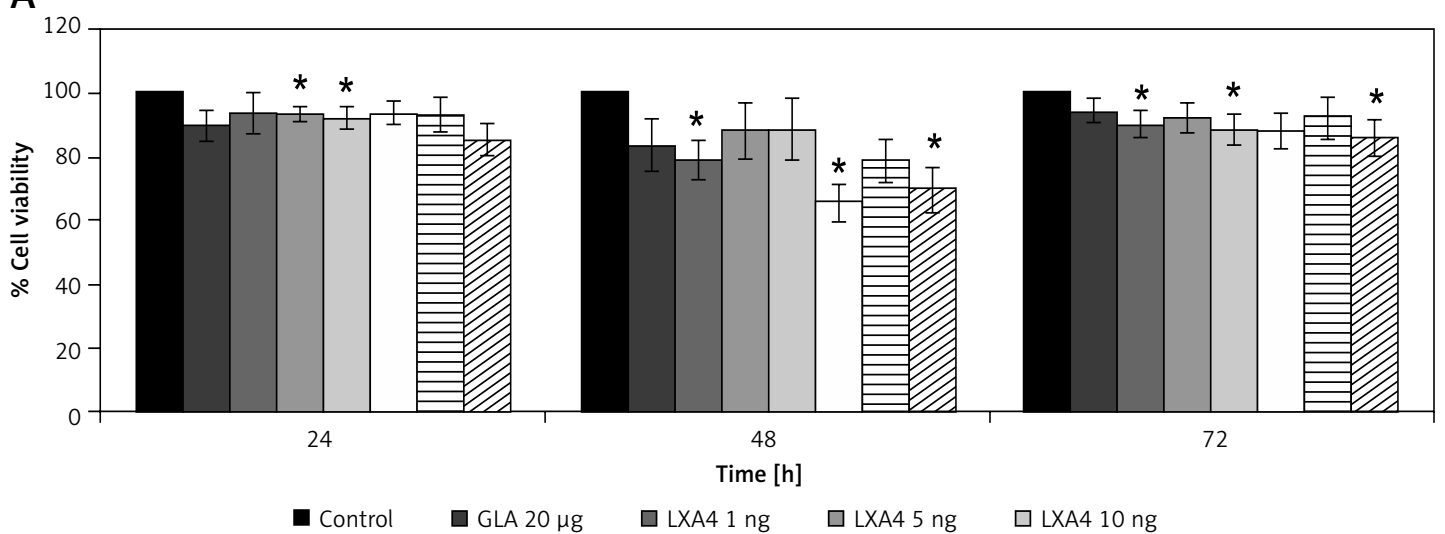

$\square \mathrm{GLA} 20 \mu \mathrm{g}+\mathrm{LXA4} 1 \mathrm{ng} \quad$ घGLA $20 \mu \mathrm{g}+\mathrm{LXA4} 5 \mathrm{ng} \quad \boxminus \mathrm{GLA} 20 \mu \mathrm{g}+\mathrm{LXA4} 10 \mathrm{ng}$

B

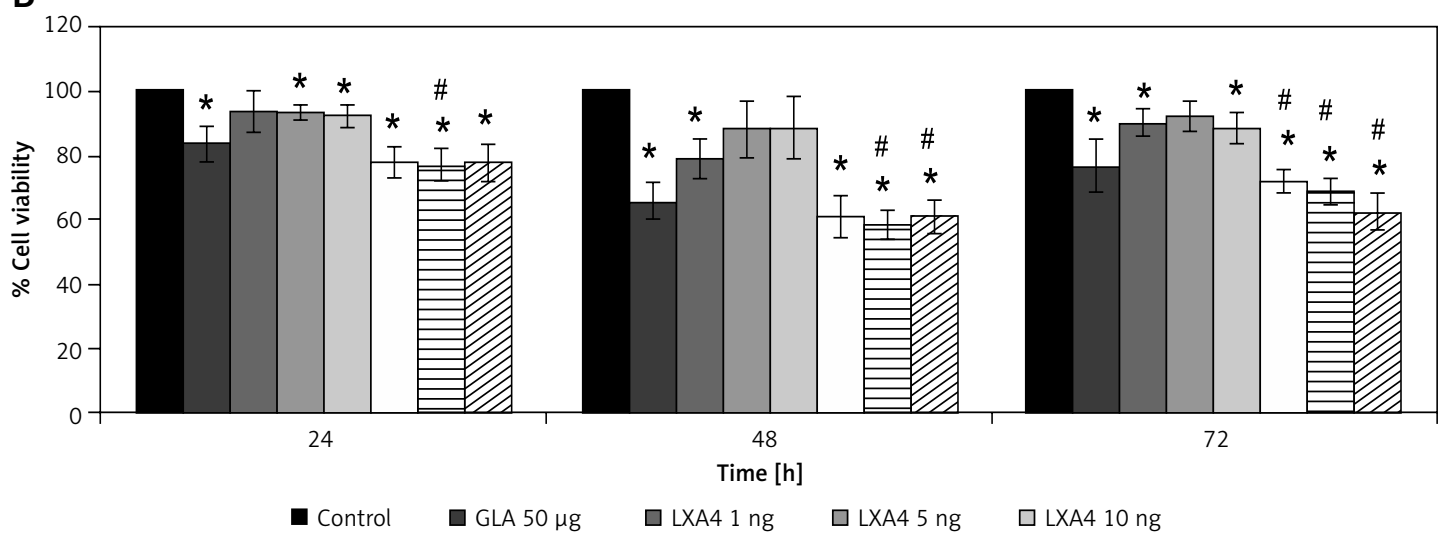

$\square \mathrm{GLA} 50 \mu \mathrm{g}+\mathrm{LXA4} 1 \mathrm{ng} \quad$ 曰GLA $50 \mu \mathrm{g}+\mathrm{LXA4} 5 \mathrm{ng} \quad \boxminus \mathrm{GLA} 50 \mu \mathrm{g}+\mathrm{LXA4} 10 \mathrm{ng}$

C

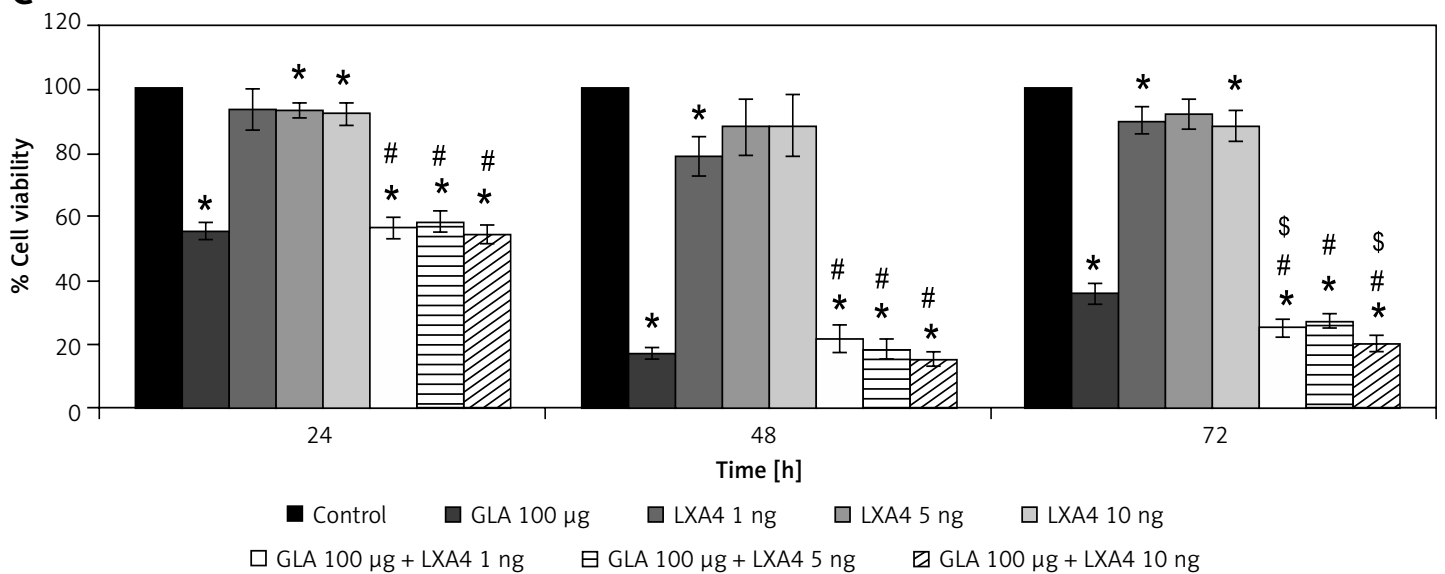

Figure 9. Effect of combination of GLA and LXA4 on survival of IMR-32 cells at the end of 24,48 and $72 \mathrm{~h}$ of incubation in vitro. A - IMR-32 cells were exposed to GLA $20 \mu \mathrm{g} / \mathrm{ml}$ and different doses $(1,5,10 \mathrm{ng} / \mathrm{ml})$ of LXA4 simultaneously and incubated for 24,48 and $72 \mathrm{~h}$. At the end of the treatment period, cell viability was measured by MTT assay. B - IMR-32 cells were exposed to GLA $50 \mu \mathrm{g} / \mathrm{ml}$ and different doses $(1,5,10 \mathrm{ng} / \mathrm{ml})$ of LXA4 simultaneously and incubated for 24,48 and $72 \mathrm{~h}$. At the end of the treatment period, cell viability was measured by MTT assay. C - IMR-32 cells were exposed to GLA $100 \mu \mathrm{g} / \mathrm{ml}$ and different doses $(1,5,10 \mathrm{ng} / \mathrm{ml}$ ) of LXA4 simultaneously and incubated for 24, 48 and $72 \mathrm{~h}$. At the end of the treatment period, cell viability was measured by MTT assay All values are expressed as mean \pm standard error $(n=6)$. ${ }^{*} P<0.05$ when compared to control; ${ }^{*} p<0.05$ when compared to $L X A 4$; ${ }^{s} p<0.05$ when compared to GLA. GLA - $\gamma$-linolenic acid, LXA4-lipoxin A4. 

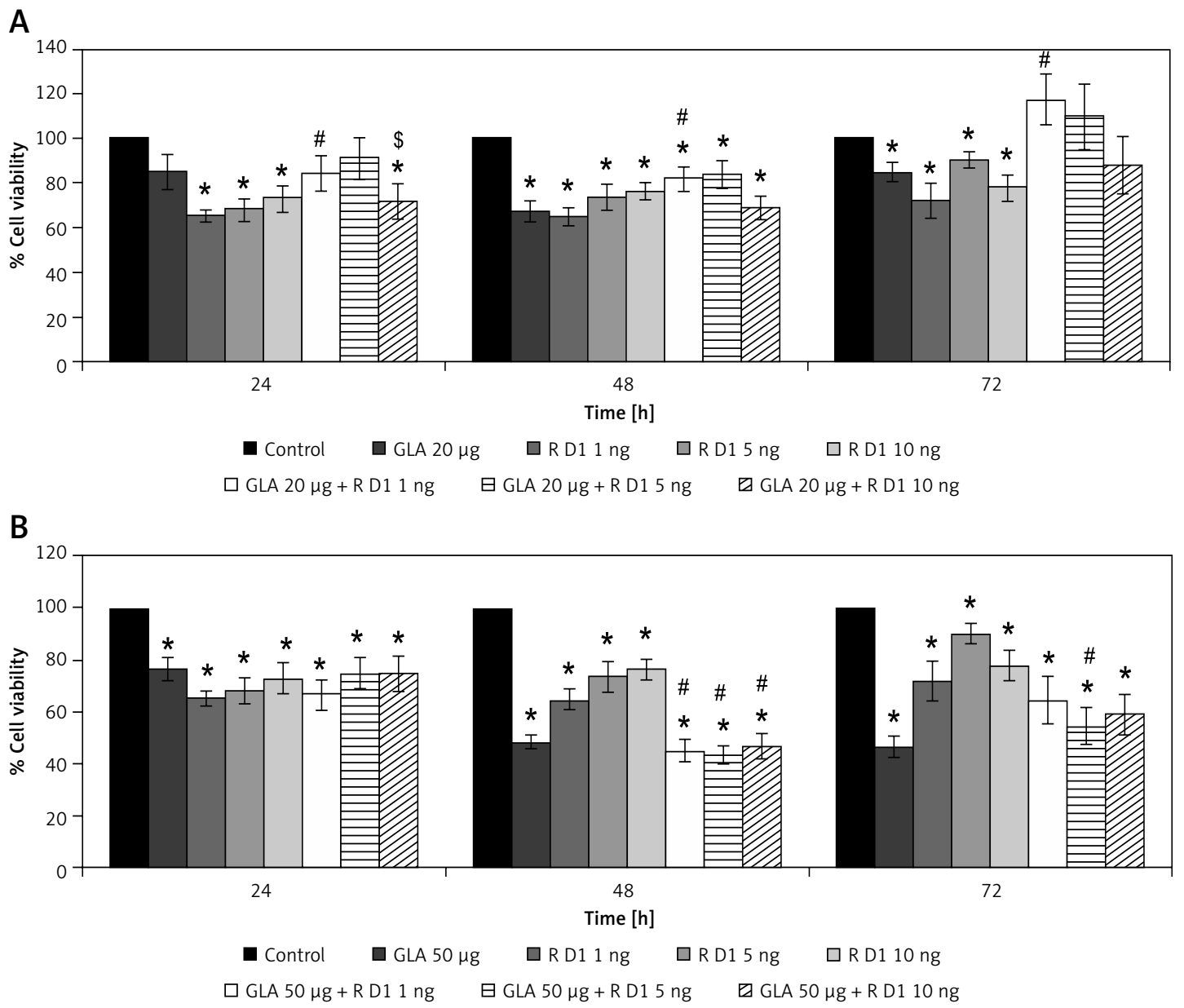

C

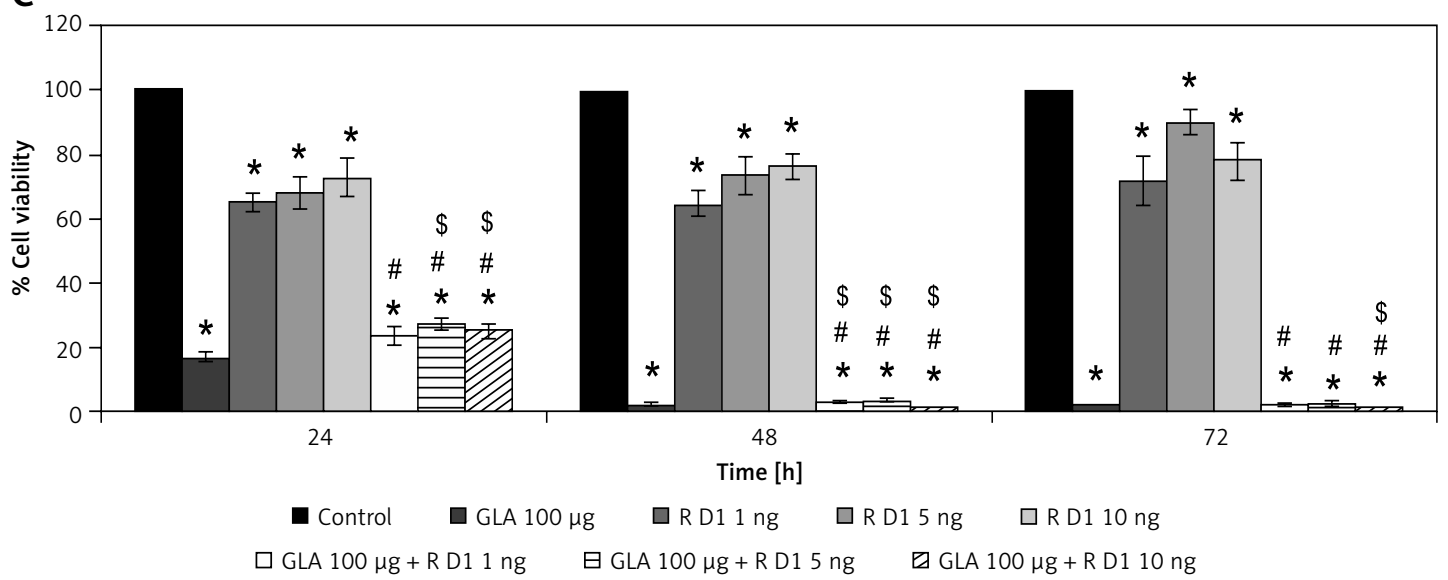

Figure 10. Effect of combination of GLA and resolvin D1 on survival of IMR-32 cells in vitro. A - IMR-32 cells were exposed to GLA $20 \mu \mathrm{g} / \mathrm{ml}$ and different doses $(1,5,10 \mathrm{ng} / \mathrm{ml})$ of resolvin D1 simultaneously and incubated for 24, 48 and $72 \mathrm{~h}$. At the end of the treatment period, cell viability was measured by MTT assay. B - IMR-32 cells were exposed to GLA $50 \mu \mathrm{g} / \mathrm{ml}$ and different doses $(1,5,10 \mathrm{ng} / \mathrm{ml})$ of resolvin D1 simultaneously and incubated for 24 , 48 and $72 \mathrm{~h}$. At the end of the treatment period, cell viability was measured by MTT assay. C - IMR-32 cells were exposed to GLA $100 \mu \mathrm{g} / \mathrm{ml}$ and different doses $(1,5,10 \mathrm{ng} / \mathrm{ml})$ of resolvin D1 simultaneously and incubated for 24 48 and $72 \mathrm{~h}$. At the end of the treatment period, cell viability was measured by MTT assay

All values are expressed as mean \pm standard error $(n=6)$. ${ }^{*} P<0.05$ when compared to control; ${ }^{*} p<0.05$ when compared to resolvin $D 1 ; s p<0.05$ when compared to GLA. GLA - $\gamma$-linolenic acid, R D 1 - resolvin D1. 
A

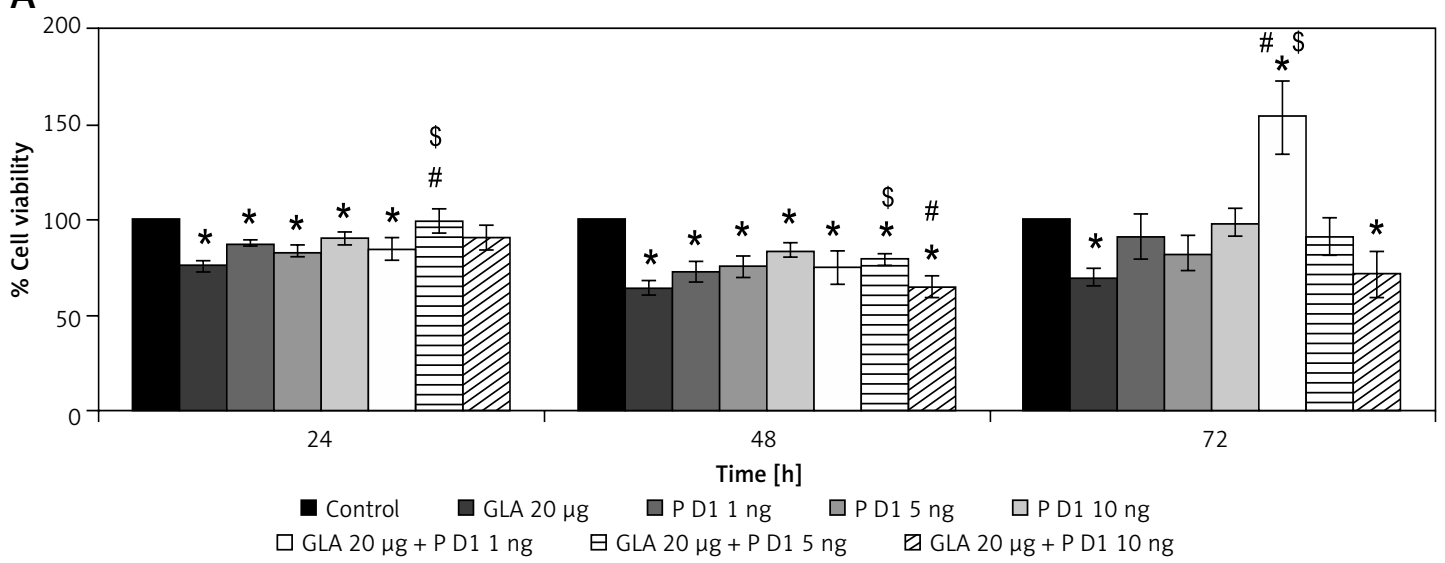

B

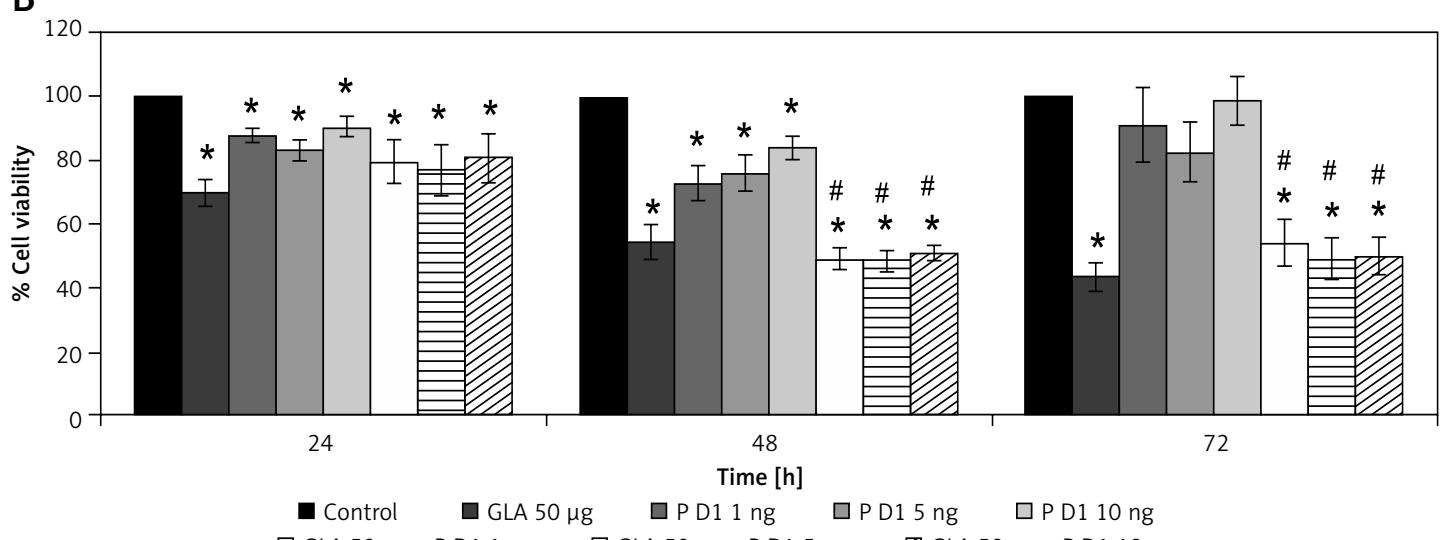

$\square$ GLA $50 \mu \mathrm{g}+\mathrm{PD} 11 \mathrm{ng} \quad$ 曰GLA $50 \mu \mathrm{g}+\mathrm{PD} 15 \mathrm{ng} \quad \square \mathrm{GLA} 50 \mu \mathrm{g}+\mathrm{PD} 110 \mathrm{ng}$

C

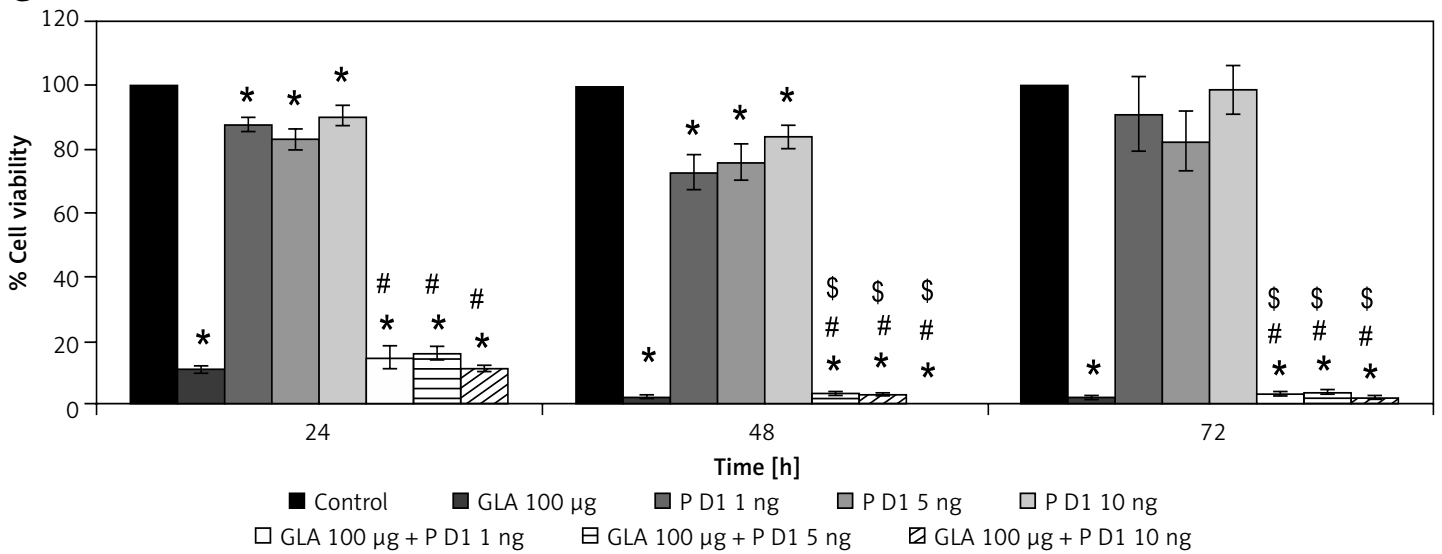

Figure 11. Effect of combination of GLA and protectin D1 on the survival of IMR-32 cells in vitro at the end of 24 , 48 and $72 \mathrm{~h}$ of incubation. A - IMR-32 cells were exposed to GLA $20 \mu \mathrm{g} / \mathrm{ml}$ and different doses $(1,5,10 \mathrm{ng} / \mathrm{ml})$ of protectin D1 simultaneously and incubated for 24,48 and $72 \mathrm{~h}$. At the end of the treatment period, cell viability was measured by MTT assay. B - IMR-32 cells were exposed to GLA 50 Mg/ml and different doses (1, 5, $10 \mathrm{ng} / \mathrm{ml})$ of protectin D1 simultaneously and incubated for 24,48 and $72 \mathrm{~h}$. At the end of the treatment period, cell viability was measured by MTT assay. C - IMR-32 cells were exposed to GLA $100 \mu \mathrm{g} / \mathrm{ml}$ and different doses $(1,5,10 \mathrm{ng} / \mathrm{ml})$ of protectin D1 simultaneously and incubated for 24, 48 and $72 \mathrm{~h}$. At the end of the treatment period, cell viability was measured by MTT assay

All values are expressed as mean \pm standard error $(n=6)$. ${ }^{*} P<0.05$ when compared to control; ${ }^{*} p<0.05$ when compared to protectin D $1 ;{ }^{s} p<0.05$ when compared to GLA. GLA - $\gamma$-linolenic acid, P D 1 - protectin D 1. 


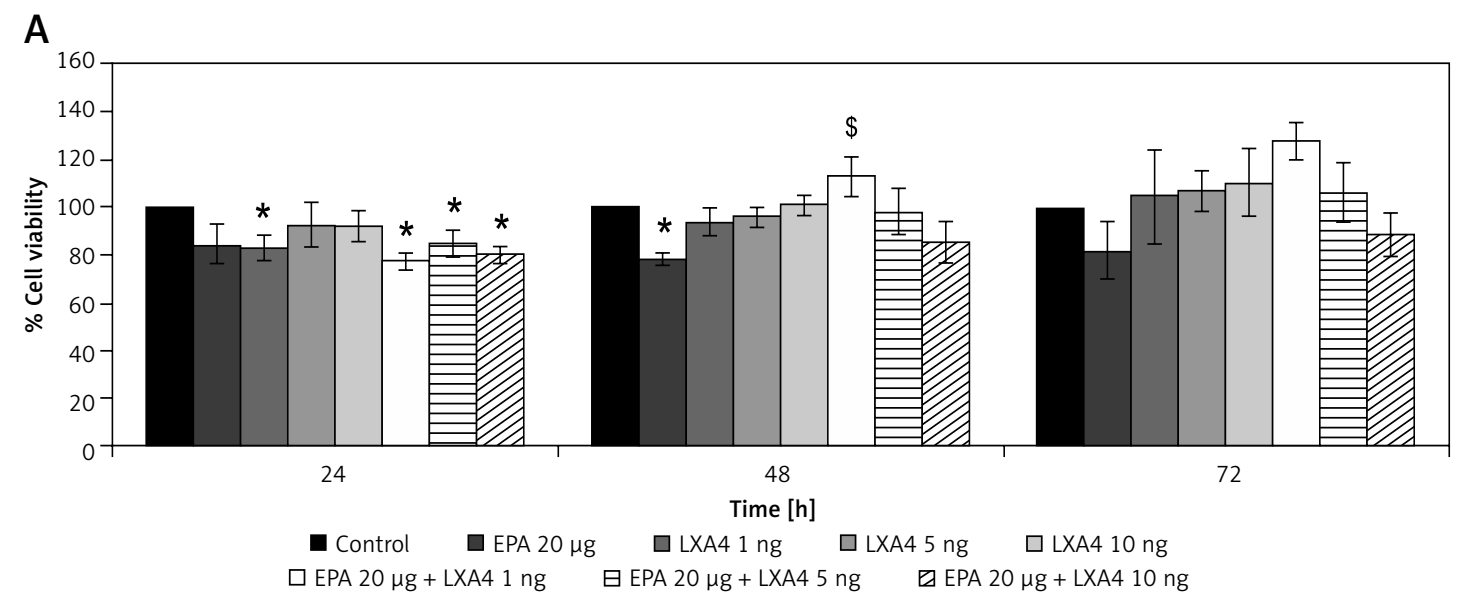

B

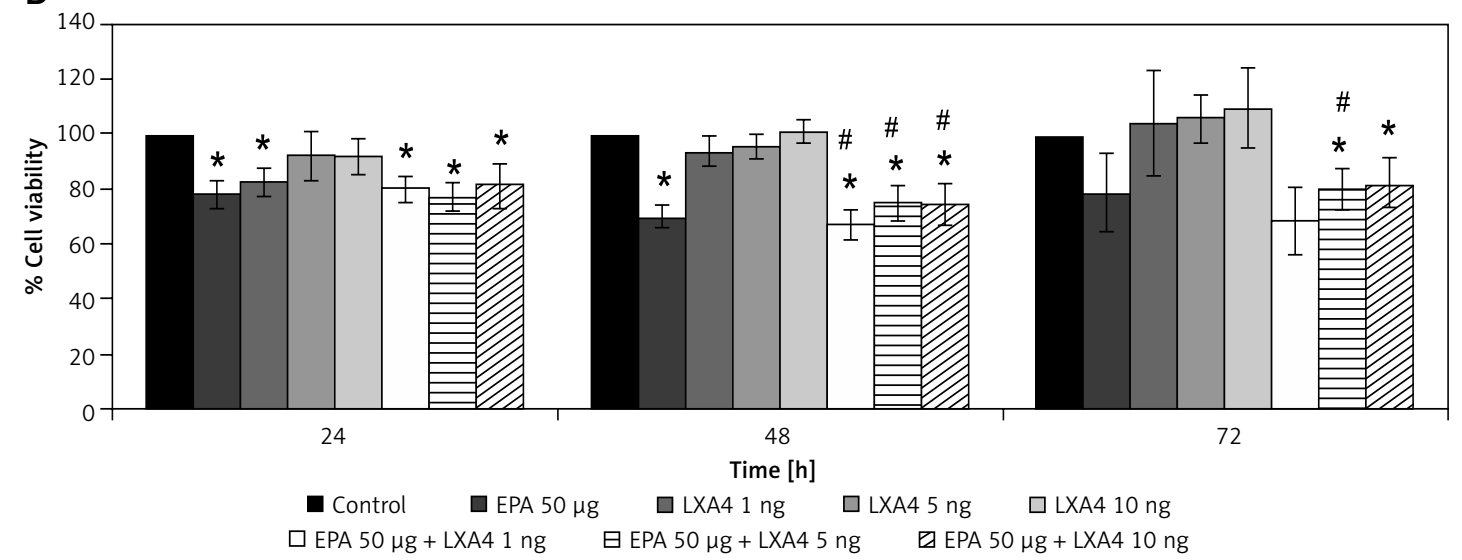

C

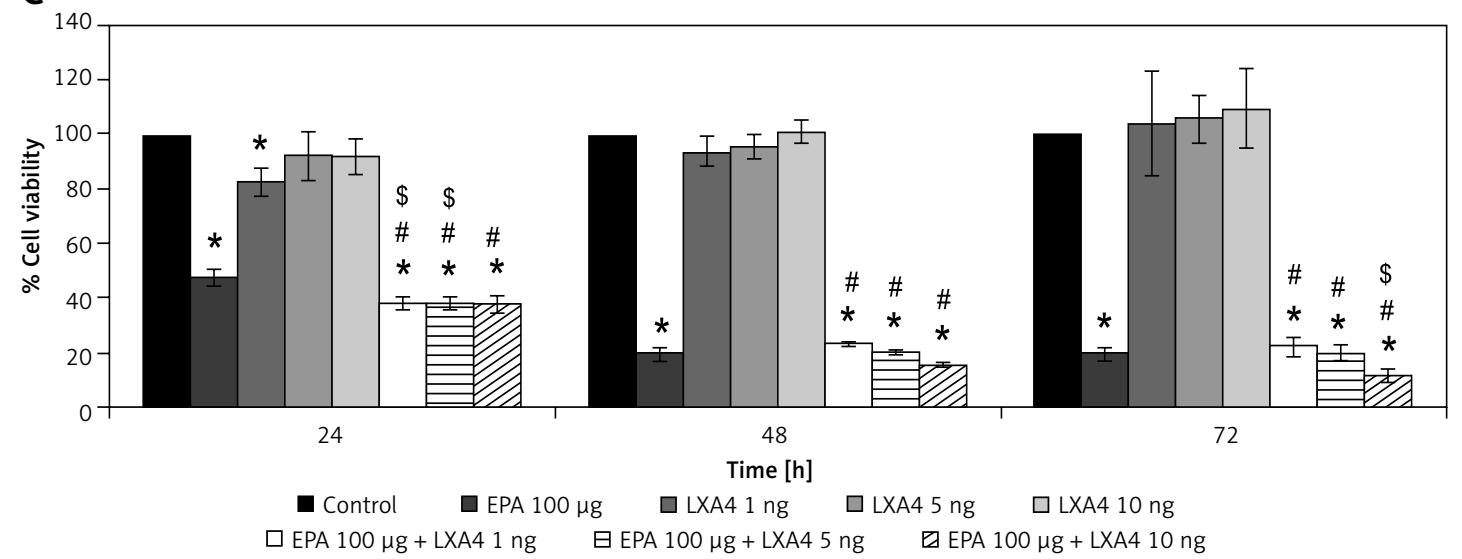

Figure 12. Effect of combination of EPA and LXA4 on survival of IMR-32 cells in vitro at the end of 24,48 and $72 \mathrm{~h}$ of incubation. A - IMR-32 cells were exposed to EPA $20 \mu \mathrm{g} / \mathrm{ml}$ and different doses $(1,5,10 \mathrm{ng} / \mathrm{ml})$ of LXA4 simultaneously and incubated for 24,48 and $72 \mathrm{~h}$. At the end of the treatment period, cell viability was measured by MTT assay. B - IMR-32 cells were exposed to EPA $50 \mu \mathrm{g} / \mathrm{ml}$ and different doses $(1,5,10 \mathrm{ng} / \mathrm{ml}$ ) of LXA4 simultaneously and incubated for 24,48 and $72 \mathrm{~h}$. At the end of the treatment period, cell viability was measured by MTT assay. C - IMR-32 cells were exposed to EPA $100 \mu \mathrm{g} / \mathrm{ml}$ and different doses $(1,5,10 \mathrm{ng} / \mathrm{ml})$ of LXA4 simultaneously and incubated for 24, 48 and $72 \mathrm{~h}$. At the end of the treatment period, cell viability was measured by MTT assay All values are expressed as mean \pm standard error $(n=6)$. ${ }^{*} P<0.05$ when compared to control; ${ }^{*} p<0.05$ when compared to $L X A 4$; ${ }^{s} p<0.05$ when compared to EPA. EPA - eicosapentaenoic acid, LXA4 - lipoxin A4. 
A

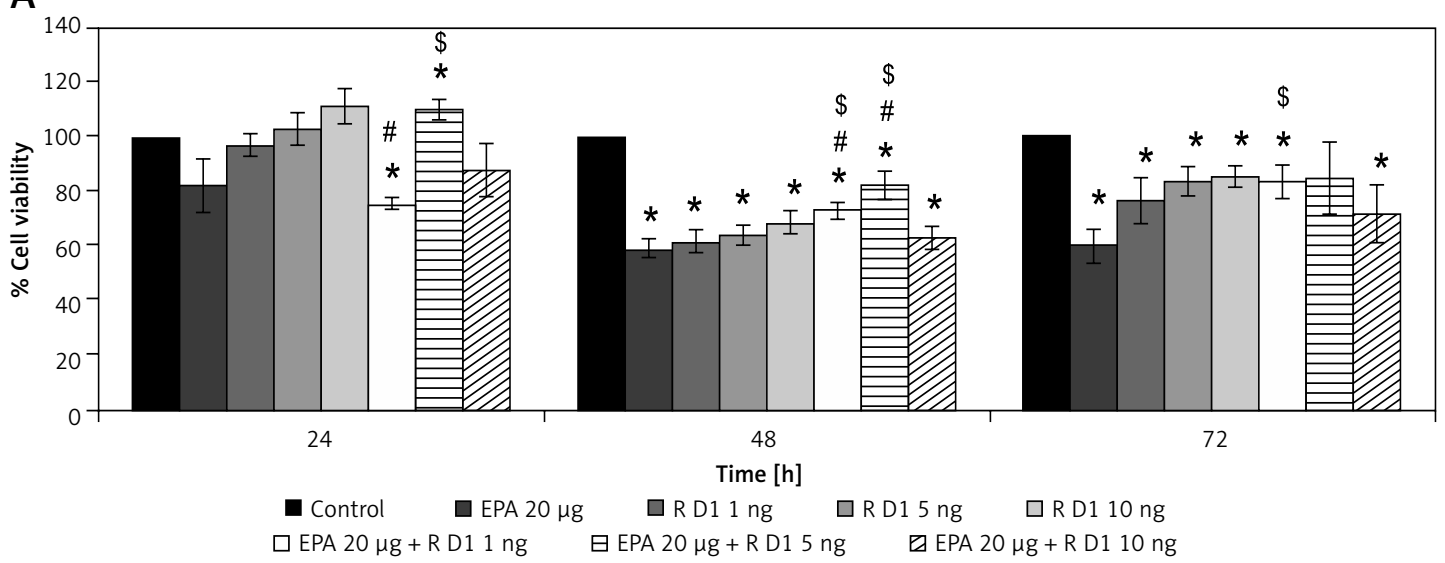

B

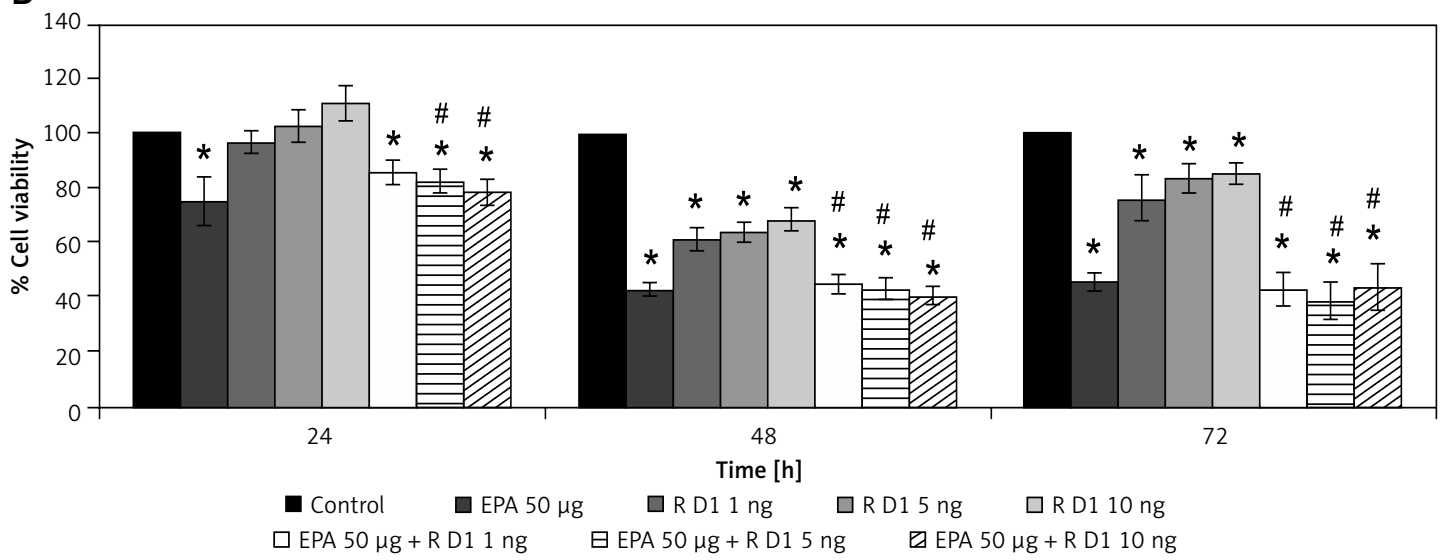

C

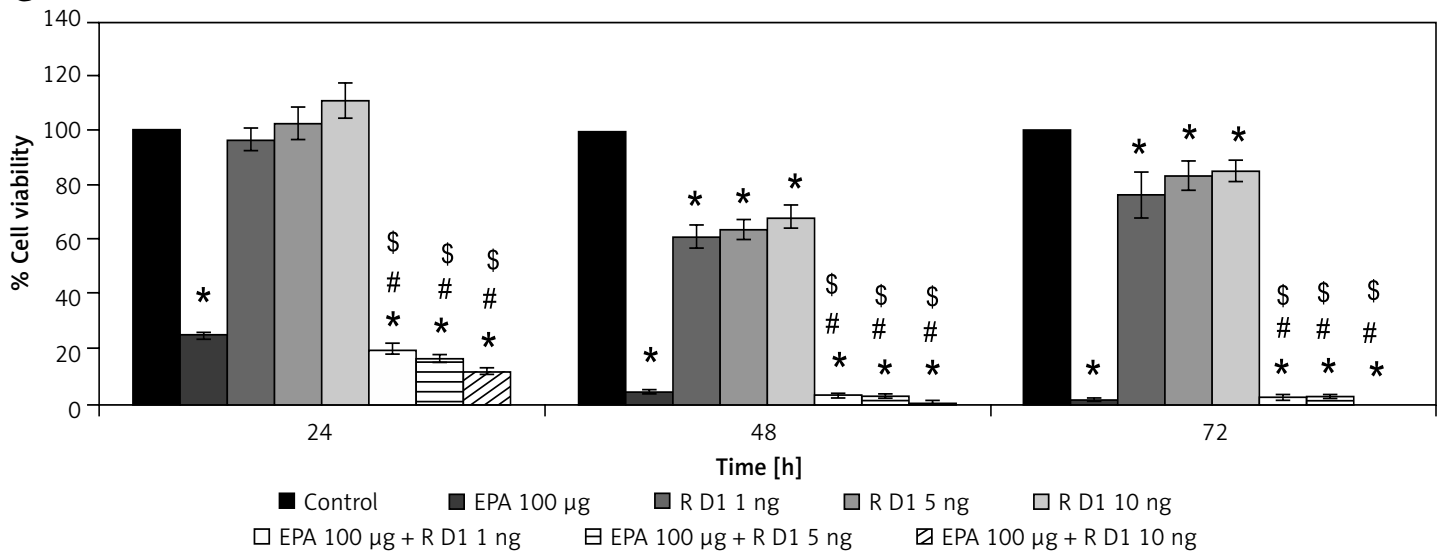

Figure 13. Effect of combination of EPA and resolvin D1 on survival of IMR-32 cells in vitro at the end of 24,48 and $72 \mathrm{~h}$ of incubation. A - IMR-32 cells were exposed to EPA $20 \mu \mathrm{g} / \mathrm{ml}$ and different doses $(1,5,10 \mathrm{ng} / \mathrm{ml})$ of resolvin D1 simultaneously and incubated for 24,48 and $72 \mathrm{~h}$. At the end of the treatment period, cell viability

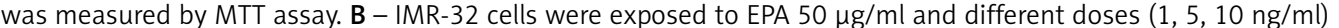
of resolvin D1 simultaneously and incubated for 24,48 and $72 \mathrm{~h}$. At the end of the treatment period, cell viability was measured by MTT assay. C - IMR-32 cells were exposed to EPA $100 \mu \mathrm{g} / \mathrm{ml}$ and different doses $(1,5,10 \mathrm{ng} / \mathrm{ml})$ of resolvin D1 simultaneously and incubated for 24, 48 and $72 \mathrm{~h}$. At the end of the treatment period, cell viability was measured by MTT assay

All values are expressed as mean \pm standard error $(n=6)$. ${ }^{*} P<0.05$ when compared to control; ${ }^{*} p<0.05$ when compared to resolvin $D 1 ;{ }^{s} p<0.05$ when compared to EPA. EPA - eicosapentaenoic acid, $R$ D 1 - resolvin D1. 

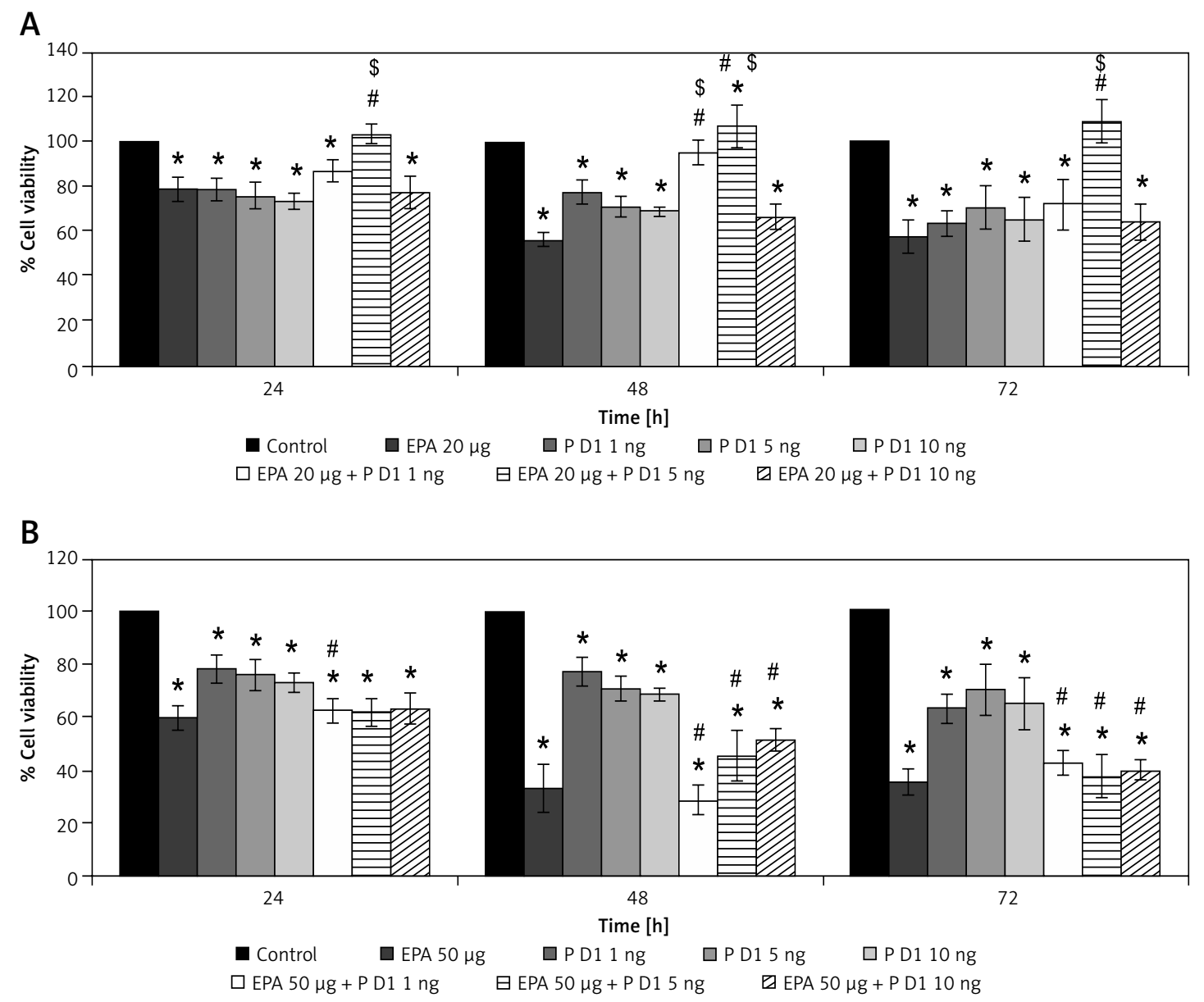

C

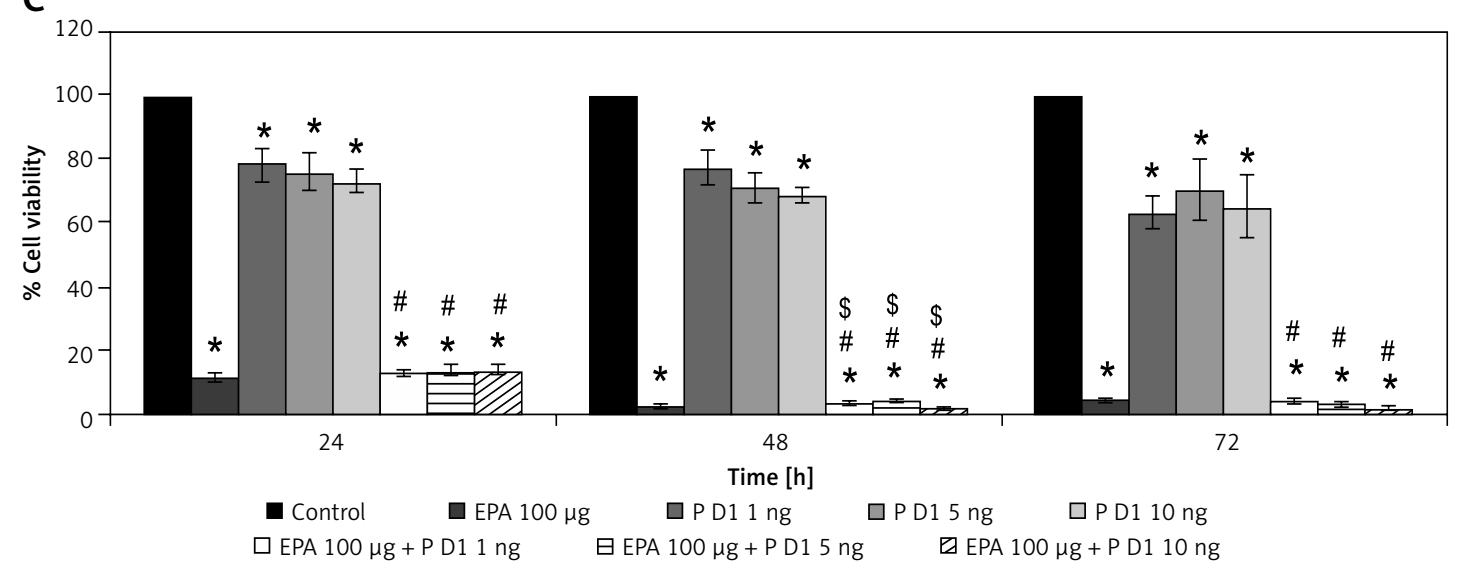

Figure 14. Effect of EPA and protectin D1 on survival of IMR-32 cells in vitro at the end of 24,48 and $72 \mathrm{~h}$ of incubation. A - IMR-32 cells were exposed to EPA $20 \mu \mathrm{g} / \mathrm{ml}$ and different doses (1, 5, $10 \mathrm{ng} / \mathrm{ml})$ of protectin D1 simultaneously and incubated for 24, 48 and $72 \mathrm{~h}$. At the end of the treatment period, cell viability was measured by MTT assay. B - IMR-32 cells were exposed to EPA $50 \mu \mathrm{g} / \mathrm{ml}$ and different doses (1, 5, $10 \mathrm{ng} / \mathrm{ml})$ of protectin D1 simultaneously and incubated for 24,48 and $72 \mathrm{~h}$. At the end of the treatment period, cell viability was measured by MTT assay. C - IMR-32 cells were exposed to EPA $100 \mu \mathrm{g} / \mathrm{ml}$ and different doses (1, 5, $10 \mathrm{ng} / \mathrm{ml})$ of protectin D1 simultaneously and incubated for 24, 48 and $72 \mathrm{~h}$. At the end of the treatment period, cell viability was measured by MTT assay

All values are expressed as mean \pm standard error $(n=6)$. ${ }^{*} P<0.05$ when compared to control; ${ }^{*} p<0.05$ when compared to protectin D $1 ;{ }^{s} p<0.05$ when compared to EPA. EPA - eicosapentaenoic acid, P D1 - protectin D1. 
exposed to different doses $(10,20$ and $30 \mu \mathrm{g} / \mathrm{ml})$ for $32 \mathrm{~h}$ and $40 \mathrm{~h}$ and EPA showed a significant $(p<0.05)$ reduction of viability at both time periods tested in a dose-dependent manner. Other PUFAs tested had no effect on the viability of human lymphocytes at the doses used (Figures 2 C-F).

\section{Effect of lipoxin A4}

There were no significant changes in the viability of the human lymphocytes (Figure $15 \mathrm{~A}$ ), when exposed to different doses of lipoxin A4 (1, 5 and $10 \mathrm{ng} / \mathrm{ml}$ ) and incubated for $40 \mathrm{~h}$.

\section{Effect of PUFAs and their metabolite on bleomycin-induced cytotoxicity on human lymphocytes in vitro}

In order to determine whether PUFAs and their metabolite (lipoxin A4) alter the growth inhibitory action of bleomycin on human lymphocytes in vitro, we studied the effect of pre- and simultaneous exposure of these cells to PUFAs, lipoxin A4 and bleomycin.

A

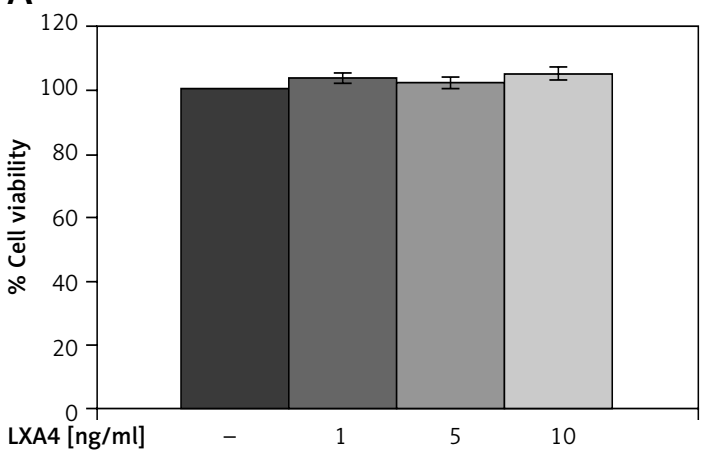

C

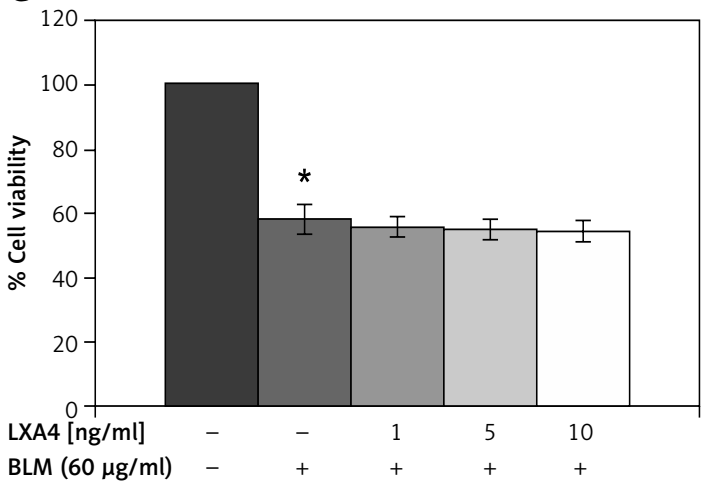

\section{Effect of PUFAs}

In both pre- and simultaneous treatment schedules, PUFAs did not augment the growth inhibitory effect of bleomycin on human lymphocytes (Figures 16, 17).

\section{Effect of lipoxin A4}

Both pre- and simultaneous treatment with lipoxin A4 did not produce any significant change in the growth inhibitory effects of bleomycin on human lymphocytes in vitro (Figures 15 B-D).

\section{Discussion}

Bleomycin, a glycopeptide antibiotic, is used in the treatment of Hodgkin's lymphoma, squamous cell carcinomas, and testicular cancer as a component of ABVD (Adriamycin, bleomycin, vinblastine and dacarbazine) and BEACOPP (bleomycin, etoposide, Adriamycin, cyclophosphamide, Oncovin = vincristine, procarbazine, prednisone). Bleomycin acts by inducing DNA strand breaks and

B

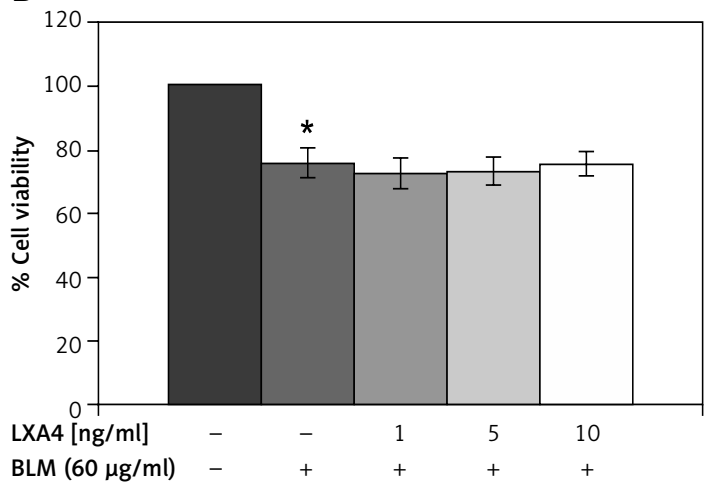

D

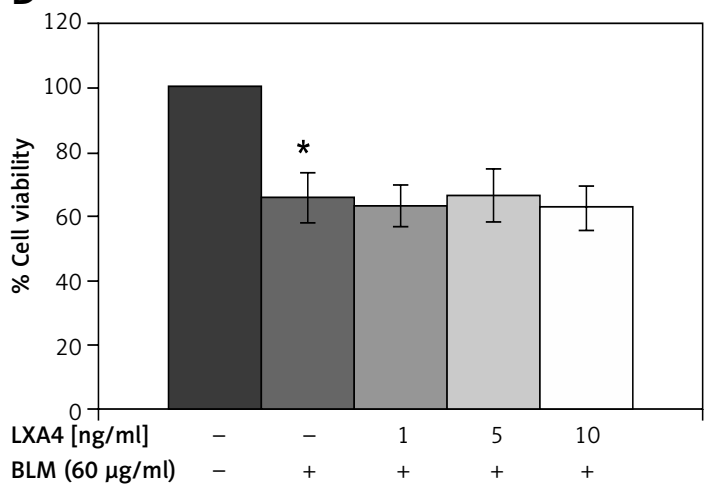

Figure 15. Effect of lipoxin A4 on viability of human lymphocytes with and without bleomycin. Human lymphocytes were exposed to different doses $(1,5,10 \mathrm{ng} / \mathrm{ml})$ of lipoxin A4 and incubated for $40 \mathrm{~h}$ (A). Effect of simultaneous treatment with different doses $(1,5,10 \mathrm{ng} / \mathrm{ml})$ of lipoxin A4 on bleomycin $(60 \mu \mathrm{g} / \mathrm{ml})$-induced cytotoxicity to human lymphocytes. Cells were incubated with simultaneously added lipoxin A4 and bleomycin for $40 \mathrm{~h}$ (B). Effect of pre-treatment with different doses $(1,5,10 \mathrm{ng} / \mathrm{ml})$ of lipoxin A4 on bleomycin $(60 \mu \mathrm{g} / \mathrm{ml})$-induced cytotoxicity to human lymphocytes. Cells were pre-incubated with lipoxin A4 for $4 \mathrm{~h}$ (C) and $8 \mathrm{~h}$ (D) and then cells were supplemented with bleomycin for an additional $40 \mathrm{~h}$. At the end of the treatment period, cell viability was measured by MTT assay

All values are expressed as mean \pm standard error $(n=6)$. ${ }^{*} P<0.05$ when compared to control. BLM - bleomycin, LXA4- lipoxin A4. 
A

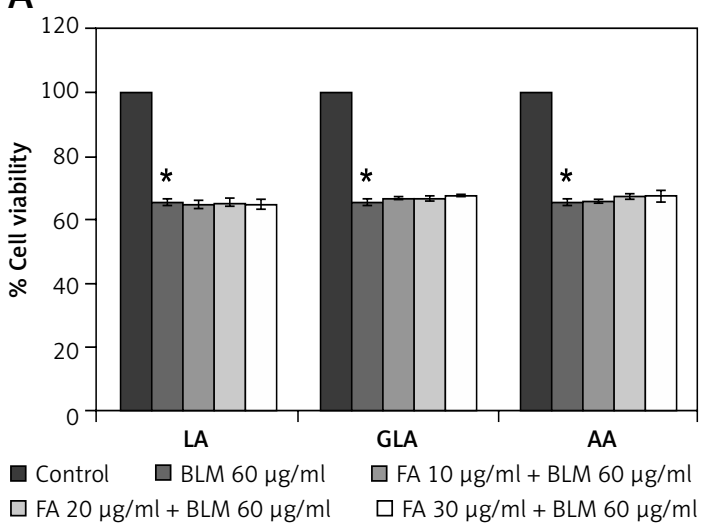

C

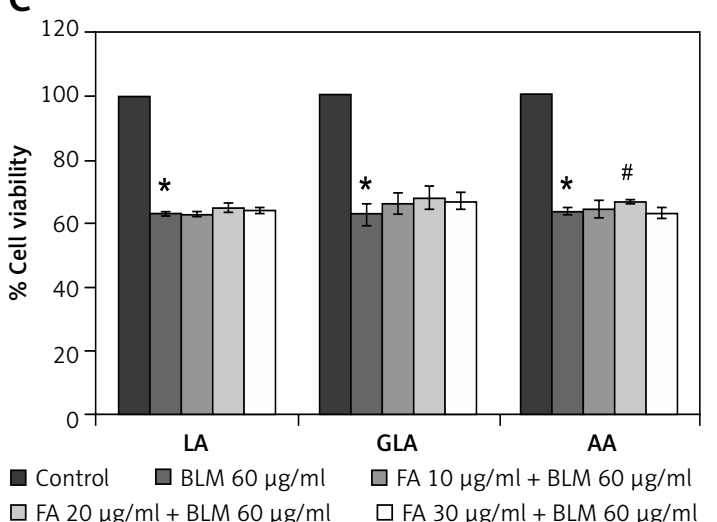

B

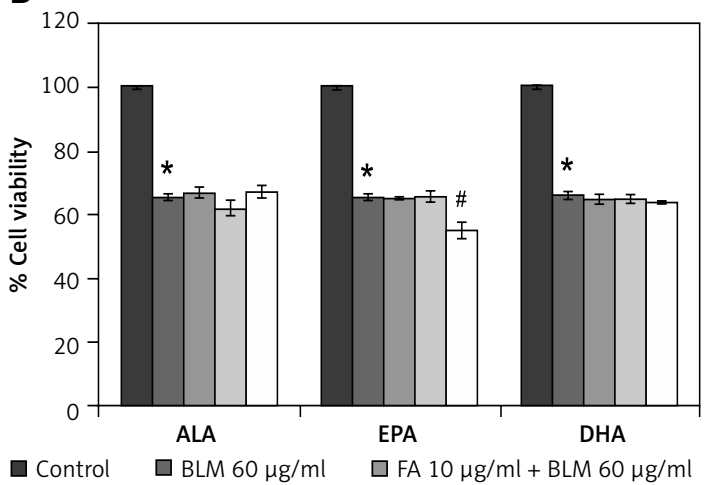

$\begin{array}{ll}\square \text { CA } 20 \mu \mathrm{g} / \mathrm{ml}+\mathrm{BLM} 60 \mu \mathrm{g} / \mathrm{ml} & \square \mathrm{FA} 30 \mu \mathrm{g} / \mathrm{ml}+\mathrm{BLM} 60 \mu \mathrm{g} / \mathrm{ml}\end{array}$

D

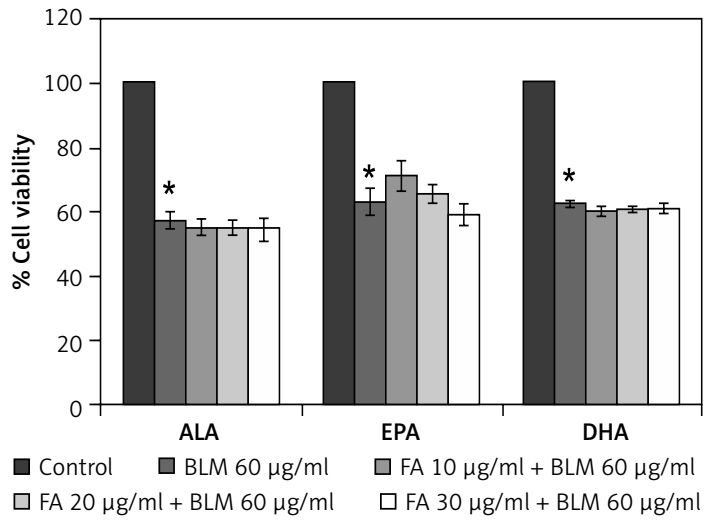

Figure 16. Effect of pre-treatment with PUFAs on bleomycin-induced cytotoxicity to human lymphocytes. Effect of pre-treatment with different doses $(10,20,30 \mu \mathrm{g} / \mathrm{ml})$ of $n-6(\mathbf{A}, \mathbf{C})$ and $n-3$ (B, D) PUFAs on bleomycin (60 $\mathrm{\mu g} /$ $\mathrm{ml}$ )-induced cytotoxicity to human lymphocytes. Cells were pre-incubated with PUFAs for $8 \mathrm{~h}(\mathbf{A}, \mathbf{B})$ and $12 \mathrm{~h}(\mathbf{C}, \mathbf{D})$ and then supplemented with bleomycin for an additional $40 \mathrm{~h}$. MTT assay was performed

All values are expressed as mean \pm standard error $(n=6)$. ${ }^{*} P<0.05$ when compared to control; ${ }^{*} p<0.05$ when compared to bleomycin. $L A$ - linoleic acid, AA - arachidonic acid, GLA - $\gamma$-linolenic acid, ALA - $\alpha$-linolenic acid, DHA - docosahexaenoic acid, EPA - eicosapentaenoic acid, BLM - bleomycin.

can inhibit DNA synthesis. Bleomycin can produce superoxide and hydroxyl radicals that can induce DNA strand breaks. Bleomycin may also bind at specific sites in the DNA strand and induce scission [47]. In addition, bleomycin can enhance the formation of lipid peroxidation [42, 48, 49]. Our previous studies revealed that some PUFAs such as GLA, DGLA, PGE1 and PGI2 protect bone marrow cells of mice from the mutagenic actions of radiation and chemicals such as benzo(a)pyrene, $4 \alpha$-phorbol and diphenylhydantoin both in vitro and in vivo [50-54]. Since bleomycin is a radiomimetic agent, in continuation of previous studies, we now evaluated the influence of various PUFAs and their pro- and anti-inflammatory metabolites on the cytotoxic action of bleomycin on normal human lymphocytes and IMR-32 cells in vitro.

Furthermore, PUFAs inhibit both normal and tumor cell growth in vitro (tumor cells $>$ normal cells) and induce respiratory burst and free radical generation both by polymorphonuclear leukocytes and tumor cells [55-58]. Since PUFAs enhance free radical generation and thus are cytotoxic to tumor cells, bleomycin can also augment free radical production [48]. Results of the present studies (Figure 5) suggest that PUFAs may potentiate the anti-cancer action of bleomycin. These results agree with previously reported studies showing that unsaturated fatty acids enhance tumoricidal action of anti-cancer drugs [7, 18-23]. This synergism in the tumoricidal action of various known anti-cancer drugs and PUFAs has been linked to increased formation of lipid peroxidation products and alteration in the concentrations of various antioxidants in tumor cells. Previously, we observed that bleomycin and AA significantly enhanced cellular content of lipid peroxides and altered their concentrations of antioxidants in IMR-32 cells in vitro [42]. Some of the other mechanisms by which PUFAs bring about their actions include changes in the formation/concentrations of eicosanoids, PPARs, protein kinase C/extracellular signal regulated kinase pathway-dependent induction of c-Myc expression, Bcl-2 expression and Gs-axin-beta-catenin signaling axis in tumor cells [24, 25-42]. 
A

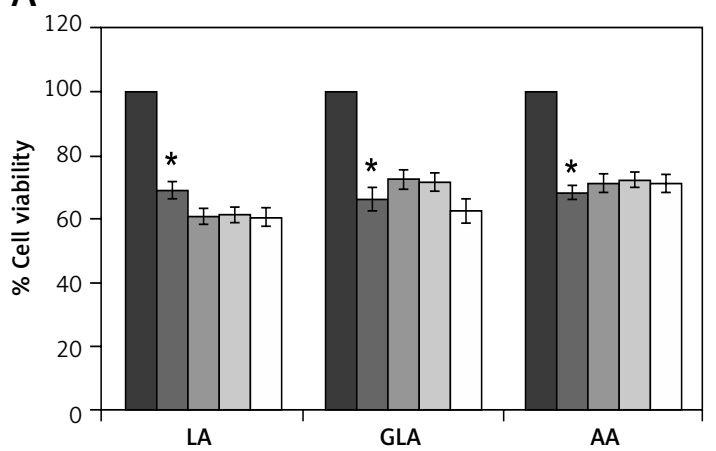

$\square$ Control $\square$ BLM $60 \mu \mathrm{g} / \mathrm{ml}$ $\square \mathrm{FA} 20 \mu \mathrm{g} / \mathrm{ml}+\mathrm{BLM} 60 \mu \mathrm{g} / \mathrm{ml}$

C

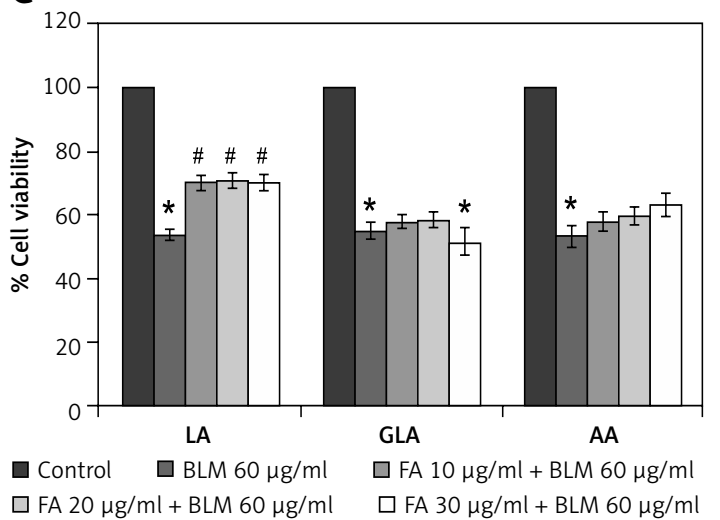

B

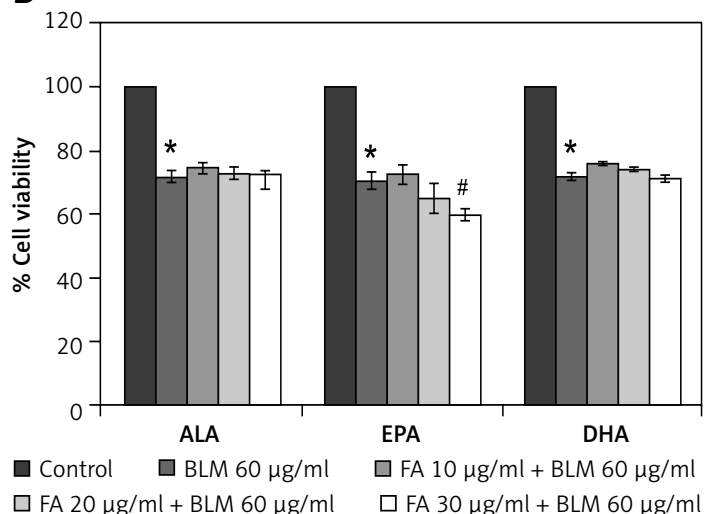

D

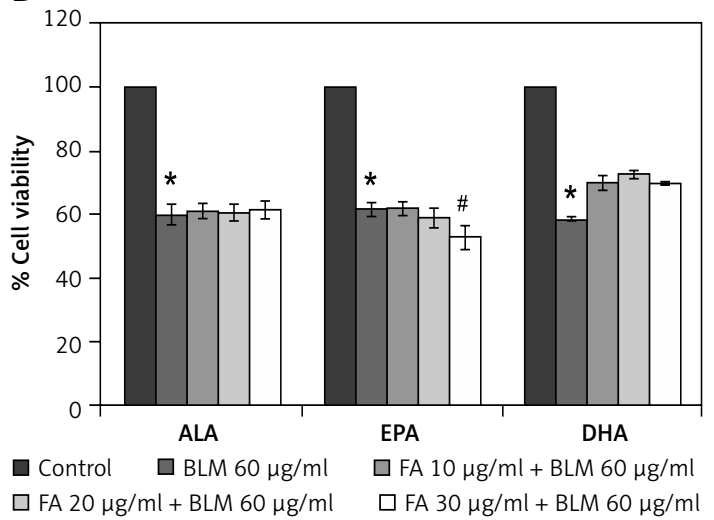

Figure 17. Effect of simultaneous treatment with PUFAs and bleomycin on viability of human lymphocytes. Effect of simultaneous treatment with different doses $(10,20,30 \mu \mathrm{g} / \mathrm{ml})$ of $n-6(\mathbf{A}, \mathbf{C})$ and $n-3(\mathbf{B}, \mathbf{D})$ PUFAs on bleomycin $(60 \mu \mathrm{g} / \mathrm{ml})$-induced cytotoxicity to human lymphocytes. PUFAs and bleomycin were added to cells and incubated for $32 \mathrm{~h}(\mathbf{A}, \mathbf{B})$ and $40 \mathrm{~h}(\mathbf{C}, \mathbf{D})$. MTT assay was performed

All values are expressed as mean \pm standard error $(n=6)$. ${ }^{*} p<0.05$ when compared to control; ${ }^{*} p<0.05$ when compared to bleomycin. $L A$ - linoleic acid, AA - arachidonic acid, GLA - $\gamma$-linolenic acid, ALA - $\alpha$-linolenic acid, DHA - docosahexaenoic acid, EPA - eicosapentaenoic acid, BLM - bleomycin.

The results of the present study revealed that growth inhibitory action of bleomycin is influenced by various PUFAs and their metabolites. The results of the present study revealed that metabolites of PUFAs - lipoxin A4 (LXA4), resolvin D1 and protectin D1 - by themselves inhibit the growth of IMR-32 cells while prostaglandins are not very effective. On the other hand, bleomycin-induced growth inhibitory action on IMR-32 cells is augmented by PUFAs, LXA4, resolvin D1 and protectin D1. In contrast to this, PUFAs, LXA4, resolvin D1 and protectin D1 at the doses tested did not inhibit the growth of human lymphocytes. In addition, bleomycin-induced growth inhibitory action was also not enhanced by these bioactive lipids. These results emphasize the interesting possibility that these bioactive lipids have a differential action on normal and tumor cells in vitro. It is noteworthy that PUFAs themselves possess significant growth inhibitory action on tumor cells with little or no involvement of their metabolites such as prostaglandins, LXA4, resolvin D1 and protectin D1. Lack of augmentation of growth inhibitory action of bleomycin on human lymphocytes by PUFAs in comparison to their (bleomycin + PUFAs) growth inhibitory action on IMR-32 cells suggests that PUFAs and conventional anti-cancer drugs can be used together to selectively target tumor cells with little or no concern of a possible suppressive action of this combination on human lymphocytes. These interesting results need to be confirmed in relevant in vivo studies in future.

One of the surprising observations noted in the present study is the ability of both indomethacin and NDGA not only to abrogate the tumoricidal action of bleomycin but, in fact, to enhance the viability of IMR-32 cells. This suggests that caution needs to be exercised in the use of COX inhibitors to prevent cancer. These unexpected results with indomethacin and NDGA could be due to their possible anti-oxidant actions. It is possible that the action of aspirin, which is used to prevent colon cancer, might be different from that of indomethacin, which may account for its beneficial action. For instance, aspirin is known to enhance the production of LXA4, nitric oxide and prosta- 
cyclin (PGI2) [59-63], which may account for its beneficial action. Indomethacin has also been shown to enhance nitric oxide generation and indirectly PGI2 by its action on COX-2 enzyme and altering intracellular $\mathrm{Ca}^{2+}$ levels [64] and, in part, due to upregulation of the endothelial constitutive isoform of COX enzyme [65]. This suggests the existence of close interaction(s) among NOS (nitric oxide synthase), COX-1 and COX-2 enzymes and the formation and actions of NO, PGI2, $\mathrm{Ca}^{2+}$ levels and other eicosanoids. Thus, inhibition of one or more enzymes such as NOS, COX (COX-1 and (OX-2) enzymes and $\mathrm{Ca}^{2+}$ may produce compensatory changes in the formation of other but related bioactive chemicals, which needs to be taken into account when interpreting the results obtained while studying the actions of any one of these substances. In a similar fashion, supplementation of one PUFA may alter the concentrations and metabolism of other PUFAs and lead to unexpected and probably compensatory production of eicosanoids. This proposal is supported by the results of the present study, where we noted that bleomycin-induced growth inhibitory action on IMR-32 cells was augmented by PUFAs, LXA4, resolvin D1 and protectin D1, while these compounds did not inhibit the growth of human lymphocytes. It is also clear from the results of the present study that PUFAs themselves possess potent growth inhibitory action with little or no involvement of their metabolites such as prostaglandins, LXA4, resolvin D1 and protectin D1.

Despite the interesting results, there are certain limitations of the present study. For instance, we did not investigate in depth the basis for the different responses in the two cell types. It is likely that the ways various PUFAs are metabolized by human lymphocytes and IMR-32 cells are different and hence the differential actions noted in the present study. Previously, we proposed that normal cells may metabolize PUFAs differently compared to tumor cells, which may account for the differential action observed [44]. Hence, it is worthwhile to study how normal and tumor cells metabolize various PUFAs and the actions of these metabolites on cell proliferation and viability.

In our attempt to determine differences between effects of various PUFAs and their metabolites on a malignant and normal cell, we compared two entirely different cell types, a brain cancer with a lymphocyte. This comparison looks apparently not valid. In this context, it is noteworthy that several anti-cancer drugs including bleomycin though they are potent tumoricidal agents produce intense immunosuppression by killing lymphocytes. Hence we wanted to know whether bleomycin toxicity towards human lymphocytes is enhanced by various PUFAs and their metabo- lites. As evident from the results of the present study, it is evident that bleomycin-induced growth inhibitory action on IMR-32 cells was augmented by PUFAs, LXA4, resolvin D1 and protectin D1 but they did not inhibit the viability of human lymphocytes and bleomycin-induced growth inhibitory action was also not enhanced by these bioactive lipids. These results are reassuring and suggest that PUFAs and their metabolites such as LXA4, resolvin D1 and protectin D1 can be used in combination with bleomycin to target tumor cells with little concern that this combination will act on human lymphocytes. But, one may still argue that just because lymphocytes do not show cytotoxicity it does not establish that bleomycin would not have potentially serious toxicity against other normal tissues such as normal brain cells or other organs, such as heart, lung, kidney or bone marrow. Although this is a valid argument, it may be mentioned here that most anti-cancer drugs initially act on lymphocytes and only some specific drugs act on other normal tissues or organs. Since PUFAs and their metabolites do not seem to decrease the viability of human lymphocytes, they are unlikely to have toxic actions on other normal tissue, though this needs to be firmly established in future studies. In fact, in our previous studies we did show that PUFAs may have cytoprotective action on kidney and bone marrow cells [50-54] and other tissues that are involved in systemic diseases such as lupus [66-70]. In fact, there is strong evidence to suggest that various PUFAs, especially EPA and DHA, as well as LXA4, resolvins and protectins, have potent cytoprotective actions and prevent chemical and radiation-induced damage to several normal tissues and organs $[59,62$, 66-74]. These results imply that normal cells can metabolize various PUFAs to form beneficial and anti-inflammatory compounds such as lipoxins, resolvins and protectins, whereas probably tumor cells do not do so.

It may also be noted here that in the combinatorial effect of two treatments, RD1 (resolvin D1) (Figure 10) and PD1 (protectin D1) (Figure 11) treatments did not enhance the effect of GLA treatment alone; in fact combination treatments have values that are quite similar to the GLA treatment alone and similarly, in Figures 12-14 combinatorial treatment did not differ from the EPA treated cells; suggesting that even if tumor cells can form significant amounts of resolvin D1 and protectin D1 they do not interfere with the anti-cancer action of PUFAs.

The results of the present study are interesting in the light of the previously reported studies which showed that unsaturated fatty acids enhance tumoricidal action of anti-cancer drugs $[7,12,8-23]$. This synergism in the tumoricidal 
action of various known anti-cancer drugs and PUFAs has been linked to increased oxidative stress of the cellular membranes and compartments, such as mitochondria and endoplasmic reticulum $[12,13,75,76]$, and alteration of the concentrations of various antioxidants in tumor cells.

In addition, a recent finding that PUFA can synergize not only with different drugs but also with irradiation suggests that unsaturated fatty acids may function as drug sensitizing agents (both anti-cancer drugs and radiation), which is of significant clinical relevance. Furthermore, several studies have demonstrated that prostaglandins and PUFA can modify $\gamma$-radiation and chemicalinduced cytotoxicity and genetic damage both in vitro and in vivo $[50,51,53]$. These findings when viewed beside the results of the present study imply that a combination therapy (like bleomycin treatment) can be a preferred therapy with PUFAs in the management of cancer.

In a similar fashion, PUFAs may also be administered in combination with radiotherapy to enhance the cytotoxic action of radiation on cancer cells and at the same time protect normal cells from the cytotoxic actions of radiation since PUFAs have cytoprotective action on normal cells [77, 78].

In conclusion, the results of the present study suggest that bioactive lipids have a differential action on normal human lymphocytes and tumor cells in vitro. PUFAs in combination with bleomycin did not exacerbate the growth inhibitory action of bleomycin on human lymphocytes but did inhibit the growth inhibitory action on IMR-32 cells. These results suggest that PUFAs can be used in combination with bleomycin to target tumor cells with little concern over this combination's effect on the growth of human lymphocytes.

\section{Acknowledgments}

Current address' Bilikere S. Dwarakanath is Central Research Facility, Sri Ramachandra University, Chennai 600116, India.

\section{Conflict of interest}

The authors declare no conflict of interest.

\section{References}

1. Begin ME, Ells G, Das UN, Horrobin DF. Differential killing of human carcinoma cells supplemented with $\mathrm{n}-3$ and n-6 polyunsaturated fatty acids. J Natl Cancer Inst 1986; 77: 1053-62.

2. Das UN. Tumoricidal action of cis-unsaturated fatty acids and its relationship to free radicals and lipid peroxidation. Cancer Lett 1991; 56: 235-43.

3. Ge H, Kong X, Shi L, Hou L, Liu Z, Li P. Gamma-linolenic acid induces apoptosis and lipid peroxidation in human chronic myelogenous leukemia K562cells. Cell Biol Int 2009; 33: 402-10.
4. Begin ME, Das UN, Ells G. Cytotoxic effects of essential fatty acids (EFA) in mixed cultures of normal and malignant human cells. Prog Lipid Res 1986; 25: 573-6.

5. Das UN. From bench to the clinic: c-linolenic acid therapy of human gliomas. Prostaglandins Leukot Essent Fatty Acids 2004; 70: 539-52.

6. Gillis RC, Daley BJ, Enderson BL, Karlstad MD. Eicosapentaenoic acid and gamma-linolenic acid induce apoptosis in HL-60 cells. J Surg Res 2002; 107: 145-53.

7. Madhavi N, Das UN. Effect of $n-6$ and $n-3$ fatty acids on the survival of vincristine sensitive and resistant human cervical carcinoma cells in vitro. Cancer Lett 1994; 84: 31-41.

8. Kumar GS, Das UN. Free radical dependent suppression of mouse myeloma cells by alpha-linolenic and eicosapentaenoic acids in vitro. Cancer Lett 1995; 92: 27-38.

9. Rizoo MT, Regazzi E, Garau D, et al. Induction of apoptosis by arachidonic acid in chronic myeloid leukemia cells. Cancer Res 1999; 59: 5047-53.

10. Ramesh G, Das UN. Effect of cis-unsaturated fatty acids on Meth-A ascitic tumor cells in vitro and in vivo. Cancer Letters 1998; 123: 207-14.

11. Vartak S, McCaw R, Davis CS, Robbins MEC, Spector AA. Gamma-linolenic acid (GLA) is cytotoxic to 36B10 malignant rat astrocytoma cells but not to 'normal' rat astrocytes. Br J Cancer 1998; 77: 1612-20.

12. Puskás LG, Fehér LZ, Vizler C, et al. Polyunsaturated fatty acids synergize with lipid droplet binding thalidomide analogs to induce oxidative stress in cancer cells. Lipids Health Dis 2010; 9: 56

13. Faragó N, Fehér LZ, Kitajka K, Das UN, Puskás LG. MicroRNA profile of polyunsaturated fatty acid treated glioma cells reveal apoptosis-specific expression changes. Lipids Health Dis 2011; 10: 173.

14. Naidu MRC, Das UN, Kishan A. Intratumoral gamma-linolenic acid therapy of human gliomas. Prostaglandins Leukot Essent Fatty Acids 1992; 45: 181-4.

15. Das UN. Tumoricidal action of gamma-linolenic acid with particular reference to the therapy of human gliomas. Med Sci Res 1995; 23: 507-13.

16. Das UN, Prasad VSSV, Reddy DR. Local application of gamma-linolenic acid in the treatment of human gliomas. Cancer Lett 1995; 94: 147-55.

17. Bakshi A, Mukherjee D, Bakshi A, Banerji AK, Das UN. Gamma-linolenic acid therapy of human gliomas. Nutrition 2003; 19: 305-9.

18. Sangeetha PS, Das UN. Gamma-linolenic acid and eicosapentaenoic acid potentiate the cytotoxicity of anti-cancer drugs on human cervical carcinoma (HeLa) cells in vitro. Med Sci Res 1993; 21: 457-9.

19. Madhavi N, Das UN. Reversal of KB-3-1 and KB-Ch-8-5 tumor cell drug-resistance by cis-unsaturated fatty acids in vitro. Med Sci Res 1994; 22: 689-92.

20. Das UN, Madhavi N, Padma M, Sagar PS. Can tumor cell drug-resistance be reversed by essential fatty acids and their metabolites? Prostaglandins Leukot Essent Fatty Acids 1998; 58: 39-54.

21. Zijlstra JG, de Vries EG, Muskiet FA, Martini IA, TimmerBosscha $\mathrm{H}$, Mulder $\mathrm{NH}$. Influence of docosahexaenoic acid in vitro on intracellular adriamycin concentration in lymphocytes and human adriamycin-sensitive and -resistant small-cell lung cancer cell lines, and on cytotoxicity in the tumor cell lines. Int J Cancer 1987; 40: 850-6.

22. Buckingham LE, Balasubramanian M, Safa AR, et al. Reversal of multi-drug resistance in vitro by fatty acid-PEG-fatty acid diesters. Int J Cancer 1996; 65: 74-9. 
23. Das UN, Madhavi N. Effect of polyunsaturated fatty acids on drug-sensitive and resistant tumor cells in vitro. Lipids Health Dis 2011; 10: 159.

24. Mengeaud V, Nano JL, Fournel S, Rampal P. Effects of eicosapentaenoic acid, gamma-linolenic acid and prostaglandin E1 on three human colon carcinoma cell lines. Prostaglandins Leukot Essent Fatty Acids 1882; 47: 313-9.

25. Botha JH, Robinson KM, Leary WP. The response of human carcinoma cell lines to gammalinolenic acid with special reference to the effects of agents which influence prostaglandin and thromboxane synthesis. Prostaglandins Leukot Med 1985; 19: 63-77.

26. Botha JH, Robinson KM, Ramchurren N, Norman RJ. The role of prostaglandins in the inhibition of cultured carcinoma cell growth produced by gamma-linolenic acid. Prostaglandins Leukot Essent Fatty Acids 1989; 35: 119-23.

27. Snyder DS, Castro R, Desforges JF. Antiproliferative effects of lipoxygenase inhibitors on malignant human hematopoietic cell lines. Exp Hematol 1989; 17: 6-9.

28. Avis I, Martınez A, Tauler J, et al. Inhibitors of the arachidonic acid pathway and peroxisome proliferator-activated receptor ligands have superadditive effects on lung cancer growth inhibition. Cancer Res 2005; 65: 4181-90.

29. Scioscia KA, Snyderman CH, D'Amico F, et al. Effects of arachidonic acid metabolites in a murine model of squamous cell carcinoma. Head Neck 2000; 22: 149-55.

30. Santoro MG, Crisari A, Benedetto A, Amici C. Modulation of the growth of a human erythroleukemic cell line (K562) by prostaglandins: antiproliferative action of prostaglandin A. Cancer Res 1986; 46: 6073-7.

31. Ayyub Khan M, Tateson JE, Hoffbrand AV, Wickremasinghe RG. Evidence that endogenous generation of leukotrienes does not regulate viability of malignant haemopoietic cell lines. Leuk Res 1993; 17: 241-5.

32. Sheng H, Shao J, Morrow JD, Beauchamp RD, DuBois RN. Modulation of apoptosis and $\mathrm{Bcl}-2$ expression by prostaglandin E2 in human colon cancer cells. Cancer Res 1998; 58: 362-6.

33. Sheng H, Shao J, Washington MK, DuBois RN. Prostaglandin E2 increases growth and motility of colorectal carcinoma cells. J Biol Chem 2001; 276: 18075-81.

34. Zweifel BS, Davis TW, Ornberg RL, Masferrer JL. Direct evidence for a role of cyclooxygenase 2-derived prostaglandin E2 in human head and neck xenograft tumors. Cancer Res 2002; 62: 6706-11.

35. Castellone MD, Teramoto $\mathrm{H}$, Williams BO, Druey KM, Gutkind JS. Prostaglandin E2 promotes colon cancer cell growth through a Gs-axin-beta-catenin signaling axis. Science 2005; 310: 1504-10.

36. Yu L, Wu WK, Li ZJ, et al. Prostaglandin E(2) promotes cell viability via protein kinase C/extracellular signal regulated kinase pathway-dependent induction of c-Myc expression in human esophageal squamous cell carcinoma cells. Int J Cancer 2009; 125: 2540-6.

37. Claria J, Lee MH, Serhan CN. Aspirin-triggered lipoxins (15-epi-LX) are generated by the human lung adenocarcinoma cell line (A549)-neutrophil interactions and are potent inhibitors of cell viability. Mol Med 1996; 2: 583-96.

38. Beckman BS, Despinasse BP, Spriggs L. Actions of lipoxins A4 and B4 on signal transduction events in friend erythroleukemia cells. Proc Soc Exp Biol Med 1992; 201: 169-73.

39. Das UN. Radiation resistance, invasiveness and metastasis are inflammatory events that could be suppressed by lipoxin A4. Prostaglandins Leukot Essent Fatty Acids 2012; 86: 3-11.
40. Hao H, Liu M, Wu P, et al. Lipoxin A4 and its analog suppress hepatocellular carcinoma via remodeling tumor microenvironment. Cancer Lett 2011; 309: 85-94.

41. Chen Y, Hao H, He S, et al. Lipoxin A4 and its analogue suppress the tumor growth of transplanted $\mathrm{H} 22$ in mice: the role of antiangiogenesis. Mol Cancer Ther 2010; 9: 2164-74.

42. Sailaja P, Mani AM, Naveen KVG, Devi AD, Siresha B, Das UN. Effect of polyunsaturated fatty acids and their metabolites on bleomycin-induced cytotoxic action on human neuroblastoma cells in vitro. PLoS One 2014; 9 e114766.

43. Das UN. Lipoxins, resolvins, protectins, maresins and nitrolipids and their clinical implications with specific reference to cancer: part I. Clin Lipidol 2013; 8: 437-63.

44. Das UN. Essential fatty acids enhance free radical generation and lipid peroxidation to induce apoptosis of tumor cells. Clin Lipidol 2011; 6: 463-89.

45. Kirkova M, Kassabova T, Russanov E. In vivo effects of indomethacin-I. Activity of antioxidant enzymes and lipid peroxidation. General Pharmacology 1992; 23: 503-7.

46. Lü JM, Nurko J, Weakley SM, et al. Molecular mechanisms and clinical applications of nordihydroguaiaretic acid (NDGA) and its derivatives: an update. Med Sci Monit 2010; 16: RA93-100.

47. Hecht SM. Bleomycin: new perspectives on the mechanism of action. J Nat Prod 2000; 63: 158-68.

48. Orr FW, Adamson IY, Warner D, et al. The effects of oxygen radical: mediated pulmonary endothelial damage on cancer metastasis. Mol Cell Biochem 1988; 84: 189-98.

49. Ueta E, Osaki T, Yoneda K, Yamamoto T. Upregulation of respiratory burst of polymorphonuclear leukocytes by a bleomycin derivative, peplomycin. Free Radic Res 1995; 22: 533-44.

50. Das UN, Devi GR, Rao KP, Rao MS. Prostaglandins and their precursors can modify genetic damage induced by benzo(a)pyrene and gamma-radiation. Prostaglandins 1985; 29: 911-20.

51. Das UN, Rao KP. Effect of gamma-linolenic acid and prostaglandins $\mathrm{E} 1$ on gamma-radiation and chemicalinduced genetic damage to the bone marrow cells of mice. Prostaglandins Leukot Essent Fatty Acids 2006; 74: 165-73.

52. Shivani P, Rao KP, Chaudhury JR, et al. Effect of polyunsaturated fatty acids on diphenylhydantoin-induced genetic damage in-vitro and in vivo. Prostaglandins Leukot Essent Fatty Acids 2009; 80: 43-50.

53. Das UN, Devi R, Rao KP, Rao MS. Prostaglandins can modify gamma-radiation and chemical-induced cytotoxicity and genetic damage both in vitro and in vivo. Prostaglandins 1989; 38: 689-96.

54. Koratkar R, Das UN, Sangeetha PS, et al. Prostacyclin is a potent anti-mutagen. Prostaglandins Leukot Essent Fatty Acids 1993; 48: 175-84.

55. Das UN, Huang YS, Begin ME, Ells G, Horrobin DF. Uptake and distribution of cis-unsaturated fatty acids and their effect on free radical generation in normal and tumor cells in vitro. Free Rad Biol Med 1987; 3: 9-14.

56. Das UN, Begin ME, Ells G, Huang YS, Horrobin DF. Polyunsaturated fatty acids augment free radical generation in tumor-cells in vitro. Biochem Biophys Res Commun 1987; 145: 15-24.

57. Das UN. Tumoricidal action of cis-unsaturated fatty ac ids and their relationship to free radicals and lipid peroxidation. Cancer Lett 1991; 56: 235-43.

58. Das UN. A radical approach to cancer. Med Sci Monit 2002; 8: RA79-92. 
59. Poorani R, Bhatt AN, Dwarakanath BS, Das UN. COX-2, aspirin and metabolism of arachidonic, eicosapentaenoic and docosahexaenoic acids and their physiological and clinical significance. Eur J Pharmacol 2016; 785: 116-32.

60. Köhnke T, Gomolka B, Bilal S, et al. Acetylsalicylic acid reduces the severity of dextran sodium sulfate-induced colitis and increases the formation of anti-inflammatory lipid mediators. Biomed Res Int 2013; 2013: 748160.

61. Brezinski DA, Nesto RW, Serhan CN. Angioplasty triggers intracoronary leukotrienes and lipoxin A4. Impact of aspirin therapy. Circulation 1992; 86: 56-63.

62. Gilroy DW. New insights into the anti-inflammatory actions of aspirin-induction of nitric oxide through the generation of epilipoxins. Mem Inst Oswaldo Cruz 2005; 100 Suppl 1: 49-54.

63. Nishio E, Watanabe Y. Aspirin and salicylate enhances the induction of inducible nitric oxide synthase in cultured rat smooth muscle cells. Life Sci 1998; 63: 429-39.

64. Bolz SS, Pohl U. Indomethacin enhances endothelial NO release: evidence for a role of PGI2 in the autocrine control of calcium-dependent autacoid production. Cardiovasc Res 1997; 36: 437-44.

65. Beverelli F, Béa ML, Puybasset L, Giudicelli JF, Berdeaux A. Chronic inhibition of NO synthase enhances the production of prostacyclin in coronary arteries through upregulation of the cyclooxygenase type 1 isoform. Fundam Clin Pharmacol 1997; 11: 252-9.

66. Das UN, Mohan IK, Raju TR. Effect of corticosteroids and eicosapentaenoic acid/docosahexaenoic acid on pro-oxidant and anti-oxidant status and metabolism of essential fatty acids in patients with glomerular disorders. Prostaglandins Leukot Essent Fatty Acids 2001; 65: 197-203.

67. Das UN. Beneficial effect of eicosapentaenoic acid and docosahexaenoic acid in the management of systemic lupus erythematosus and its relationship to the cytokine network. Prostaglandins Leukot Essent Fatty Acids 1994; 51: 207-13.

68. Das UN. Beneficial action(s) of eicosapentaenoic acid/ docosahexaenoic acid and nitric oxide in systemic lupus erythematosus. Med Sci Res 1995; 23: 723-6.

69. Das UN. Current and emerging strategies for the treatment and management of systemic lupus erythematosus based on molecular signatures of acute and chronic inflammation. J Inflamm Res 2010; 3: 143-70.

70. Das UN. Lipoxins as biomarkers of lupus and other inflammatory conditions. Lipids Health Dis 2011; 10: 76.

71. Serhan CN, Chiang N, Dalli J, Levy BD. Lipid mediators in the resolution of inflammation. Cold Spring Harb Perspect Biol 2014; 7: a016311.

72. Tang H, Liu Y, Yan C, Petasis NA, Serhan CN, Gao H. Protective actions of aspirin-triggered (17R) resolvin D1 and its analogue, 17R-hydroxy-19-para-fluorophenoxy-resolvin D1 methyl ester, in C5a-dependent IgG immune complex-induced inflammation and lung injury. J Immunol 2014; 193: 3769-78.

73. Gundala NKV, Naidu VGM, Das UN. Arachidonic acid and lipoxin A4 attenuate alloxan-induced cytotoxicity to RIN5F cells in vitro and type 1 diabetes mellitus in vivo. BioFactors 2017; 43: 251-71.

74. Gundala NKV, Naidu VGM, Das UN. Arachidonic acid and lipoxin A4 attenuate streptozotocin-induced cytotoxicity to RIN5F cells in vitro and type 1 and type 2 diabetes mellitus in vivo. Nutrition 2017; 35: 61-80.

75. Zhang C, Yu H, Shen Y, Ni X, Shen S, Das UN. Polyunsaturated fatty acids trigger apoptosis of colon cancer cells through a mitochondrial pathway. Arch Med Sci 2015; 11: 1081-94.

76. Yu H, Liu Y, Pan W, Shen S, Das UN. Polyunsaturated fatty acids augment tumoricidal action of 5-fluorouracil on gastric cancer cells by their action on vascular endothelial growth factor, tumor necrosis factor-alpha and lipid metabolism related factors. Arch Med Sci 2015; 11 : 282-91.

77. Antal O, Hackler L Jr, Shen J, et al. Combination of unsaturated fatty acids and ionizing radiation on human glioma cells: cellular, biochemical and gene expression analysis. Lipids Health Dis 2014; 13: 142.

78. Antal O, Péter M, Hackler L Jr, et al. Lipidomic analysis reveals a radiosensitizing role of gamma-linolenic acid in glioma cells. Biochim Biophys Acta 2015; 1851: 1271-82. 